\title{
Uranium Co-Precipitation with Iron Oxide Minerals
}

by

M. C. Duff

Westinghouse Savannah River Company

Savannah River Site

Aiken, South Carolina 29808

J. U. Coughlin

D. B. Hunter

A document prepared for JOURNAL ARTICLE: GEOCHIMICA ET COSMOCHIMICA ACTA

DOE Contract No. DE-AC09-96SR18500

This paper was prepared in connection with work done under the above contract number with the U.S.

Department of Energy. By acceptance of this paper, the publisher and/or recipient acknowledges the U.S.

Government's right to retain a nonexclusive, royalty-free license in and to any copyright covering this paper, along with the right to reproduce and to authorize others to reproduce all or part of the copyrighted paper. 
This document was prepared in conjunction with work accomplished under Contract No. DE-AC09-96SR18500 with the U. S. Department of Energy.

\section{DISCLAIMER}

This report was prepared as an account of work sponsored by an agency of the United States Government. Neither the United States Government nor any agency thereof, nor any of their employees, makes any warranty, express or implied, or assumes any legal liability or responsibility for the accuracy, completeness, or usefulness of any information, apparatus, product or process disclosed, or represents that its use would not infringe privately owned rights. Reference herein to any specific commercial product, process or service by trade name, trademark, manufacturer, or otherwise does not necessarily constitute or imply its endorsement, recommendation, or favoring by the United States Government or any agency thereof. The views and opinions of authors expressed herein do not necessarily state or reflect those of the United States Government or any agency thereof.

This report has been reproduced directly from the best available copy.

Available for sale to the public, in paper, from: U.S. Department of Commerce, National Technical Information Service, 5285 Port Royal Road, Springfield, VA 22161, phone: (800) 553-6847, fax: (703) 605-6900

email: orders@ ntis.fedworld.gov

online ordering: http://www.ntis.gov/support/index.html

Available electronically at http://www.osti.gov/bridge

Available for a processing fee to U.S. Department of Energy and its contractors, in paper, from: U.S. Department of Energy, Office of Scientific and Technical Information, P.O. Box 62, Oak Ridge, TN 37831-0062,

phone: (865)576-8401,

fax: (865)576-5728

email: $\underline{\text { reports@ adonis.osti.gov }}$ 
WSRC-MS-2002-00322

\title{
Uranium Co-precipitation with Iron Oxide Minerals
}

MARTINE C. DUFF*, JESSICA URBANIK COUGHLIN and DOUGLAS B. HUNTER

Westinghouse Savannah River Company, Aiken, SC, USA 29808.

Formerly of: Savannah River Ecology Laboratory (SREL), Univ. of Georgia, Aiken, SC, USA, 29802.

\begin{abstract}
In oxidizing environments, the toxic and radioactive element uranium (U) is most soluble and mobile in the hexavalent oxidation state. Sorption of U(VI) on Fe-oxides minerals [such as hematite $\left(\alpha-\mathrm{Fe}_{2} \mathrm{O}_{3}\right)$ and goethite $(\alpha-\mathrm{FeOOH})$ ] and occlusion of $\mathrm{U}(\mathrm{VI})$ by Feoxide coatings are processes that can retard $\mathrm{U}$ transport in environments. In aged Ucontaminated geologic materials, the transport and the biological availability of $\mathrm{U}$ toward reduction may be limited by co-precipitation with Fe-oxide minerals. These processes also affect the biological availability of $\mathrm{U}(\mathrm{VI})$ species toward reduction and precipitation as the less soluble U(IV) species by metal-reducing bacteria.
\end{abstract}

To examine the dynamics of interactions between $\mathrm{U}(\mathrm{VI})$ and Fe oxides during crystallization, Fe-oxide phases [containing 0.5 to 5.4 mole $\% \mathrm{U} /(\mathrm{U}+\mathrm{Fe})$ ] were synthesized using solutions of $\mathrm{U}(\mathrm{VI})$ and $\mathrm{Fe}(\mathrm{III})$. Wet chemical (digestions and chemical extractions) and spectroscopic techniques were used to characterize the synthesized Fe oxide co-precipitates after rinsing in deionized water. Leaching the high mol \% U solids with concentrated carbonate solution [for sorbed and solid phase U(VI) species] typically removed most of the U leaving on average about $0.6 \mathrm{~mol} \% \mathrm{U}$. Oxalate leaching of solids with low mol \% U contents (about $1 \mathrm{~mol} \% \mathrm{U}$ or less) indicated that almost all of the $\mathrm{Fe}$ in these solids was crystalline and that most of the $\mathrm{U}$ was associated with these crystalline Fe oxides. X-ray diffraction and Fourier-transform infrared (FT-IR) spectroscopic studies indicate that hematite formation is preferred over that of goethite when the amount of $\mathrm{U}$ in the Fe-oxides exceeds $1 \mathrm{~mol} \% \mathrm{U}(\sim 4 \mathrm{wt} \% \mathrm{U})$. FT-IR and room temperature continuous wave luminescence spectroscopic studies with unleached U/Fe solids indicate a relationship between the mol \% $\mathrm{U}$ in the $\mathrm{Fe}$ oxide and the intensity or existence of the spectra features that can be assigned to $\mathrm{UO}_{2}{ }^{2+}$ species (such as the IR asymmetric $\mathrm{v}_{3}$ stretch for $\mathrm{O}=\mathrm{U}=\mathrm{O}$ for uranyl). These spectral features were undetectable in carbonate- or oxalate-leached 
solids, suggesting solid phase and sorbed $\mathrm{U}(\mathrm{VI}) \mathrm{O}_{2}{ }^{2+}$ species are extracted by the leach solutions. Uranium $\mathrm{L}_{3}$-edge X-ray absorption spectroscopic (XAFS) analyses of the unleached U-Fe oxide solids with less than $1 \mathrm{~mol} \% \mathrm{U}$ reveal that $\mathrm{U}(\mathrm{VI})$ exists with four $\mathrm{O}$ atoms at radial distances of $2.19 \AA$ and $2.36 \AA$ and second shell Fe at a radial distance at $3.19 \AA$.

Due to the large ionic radius of $\mathrm{UO}_{2}{ }^{2+}(\sim 1.8 \AA)$ relative to that of $\mathrm{Fe}^{3+}(0.65 \AA)$, the $\mathrm{UO}_{2}{ }^{2+}$ ion is unlikely to be incorporated in the place of Fe in Fe(III)-oxide structures. Solid phase U(VI) can exist as the uranyl $\left[\mathrm{U}(\mathrm{VI}) \mathrm{O}_{2}{ }^{2+}\right]$ species with two axial U-O double bonds and four or more equatorial U-O bonds or as the uranate species [such as $\gamma-\mathrm{UO}_{3}$ ] without axial U-O bonds. Our findings indicate $\mathrm{U}^{6+}$ (with ionic radii of 0.72 to $0.8 \AA$, depending on the coordination environment) is incorporated in the Fe oxides as uranate (without axial $\mathrm{O}$ atoms) until a point of saturation is reached. Beyond this excess in $U$ concentration, precipitating U(VI) forms discrete crystalline uranyl phases that resemble the uranyl oxide hydrate schoepite $\left[\mathrm{UO}_{2}(\mathrm{OH})_{2} \cdot 2 \mathrm{H}_{2} \mathrm{O}\right]$. Molecular modeling studies reveal that $\mathrm{U}^{6+}$ species could bond with $\mathrm{O}$ atoms from distorted $\mathrm{Fe}$ octahedra in the hematite structure with an environment that is consistent with the results of the XAFS. The results provide compelling evidence of $U$ incorporation within the hematite structure. 


\section{INTRODUCTION-THE GEOCHEMICAL SPECIATION OF URANIUM influences its} solubility, mobility and biological availability in the environment. Information on the speciation and dynamics of uranium $(\mathrm{U})$ geochemical behavior is used to characterize $U$ contamination in the environment, to predict nuclear waste repository performance (MORRIS et al., 1996; FRANCIS 1998; PEARCY et al., 1994) and it is of fundamental biogeochemical interest (WINDOM et al., 2000; SWARZENKSKI et al., 1999). Geochemical speciation information on $\mathrm{U}$ has been used to evaluate potential in situ remediation approaches for contaminated ground waters such as microbial reduction via natural bioattenuation at U.S. Dept. of Energy (DOE) sites (U.S. DOE, 1999; LOVELY et al., 1991; FREDRICKSON et al., 2000).

There are several mechanisms by which $\mathrm{U}$ can be immobilized in environmental systems (FIG. 1) and many of these processes influence its potential towards biological reduction. In oxidized environments, $\mathrm{U}$ exists as the highly soluble uranyl $\left[\mathrm{U}(\mathrm{VI}) \mathrm{O}_{2}{ }^{2+}\right]$ species, which has two axial $\mathrm{U}=\mathrm{O}$ double bonds. Solid phase $\mathrm{U}(\mathrm{VI})$ (FIG. 1a) is often present as the uranyl mineral schoepite $\left(\mathrm{UO}_{3} \cdot 2 \mathrm{H}_{2} \mathrm{O}\right)$ in contaminated materials, such as soils and groundwaters at U.S. DOE sites, military proving grounds, and in U ore bodies (FINCH and MURAKAMI, 1999; DUFF et al., 1998; HUNTER and BERTSCH,1998; MORRIS et al., 1996; PEARCY et al., 1994). Solid phase U(VI) can exist as the less common uranate species, which has at least three single U-O bonds and no axial double bonds are known to form (GRIFFITHS and VOLKOVICH, 1999 and references therein). Examples of these are some forms of $\mathrm{UO}_{3}$ solids and $\mathrm{U}(\mathrm{VI})$-doped perovskites like $\mathrm{La}_{2} \mathrm{MgTiO}_{6}$ (AZENHA et al., 1992; KHILLA et al., 1986; WEIGEL, 1986; TANNER et al., 1997). However, these forms have not been identified in the geologic environment (BURNS, 1999 and references therein) and they typically form at high temperature under aqueous and non-aqueous conditions (GRIFFITHS and VOLKOVICH, 1999, and references therein). Under chemically reducing conditions soluble U(VI) species can undergo biotic reduction to the sparingly soluble $\mathrm{U}(\mathrm{IV})$ species such as $\mathrm{UO}_{2(\mathrm{~s})}$ as in FIG. 1a (LOVLEY et al., 1991; DUFF et al., 1999). Uranium(IV) and (VI) solids may precipitate near or in the participating microbe in the presence of a microbial energy source (FIG. 1a and b) (FREDRICKSON et al., 2000; MACASKIE et al., 1992).

Uranium forms soluble complexes with carbonate, oxalate and hydroxide (GRENTHE et al., 1992). In the absence of high levels of complexing ligands, dissolved $\mathrm{U}$ sorbs to Fe-oxide minerals such as hematite $\left(\alpha-\mathrm{Fe}_{2} \mathrm{O}_{3}\right)$ and goethite $(\alpha-\mathrm{FeOOH})$ and organic matter over a wide range of solution pH conditions (FIG. 1c; MOYES et al., 2000; DUFF and AMRHEIN, 1996; 
WAITE et al., 1994; HSI and LANGMUIR, 1986; HO and MILLER, 1986; READ et al., 1993). Occlusion of U by Fe-oxide mineral coatings (FIG. 1d and e) (JENNE, 1977) and formation of reduced layers of $\mathrm{U}(\mathrm{IV})$ on $\mathrm{U}(\mathrm{VI})$ solids by microbial processes may also retard $\mathrm{U}$ transport (FREDRICKSON et al., 2000).

Another potential process that could influence $U$ transport and bioavailability is the coprecipitation of $U$ with oxide minerals or other naturally-occurring mineral phases such as the carbonates (e.g., REEDER et al., 2000) and silicates (FIG. 1f). This process is most likely to occur in aged U-contaminated soils and subsurface materials. Incorporation of metals into Feoxide phases is observed for a variety of transition metals (FORD et al., 1999; MARTINEZ and MCBRIDE, 1998; FORD et al., 1997; GERTH, 1990). Uranium is not thought to be incorporated into the $\alpha-\mathrm{FeOOH}$ (goethite) structure (GERTH, 1990). However, studies report the uptake of $U$ during the formation of crystalline and amorphous Fe oxides (OHNUKI et al., 1997; PLOTNIKOV and BANNYKH, 1997; SATO et al., 1997; BRUNO et al., 1995). However, these studies did not characterize the local structural speciation of the $\mathrm{U}$ in these Fe oxide materials.

The formation and dissolution of Fe minerals can occur on a cyclic basis — particularly in the presence of biologically reducing (oxidation-reduction) conditions. The incorporation of $U$ into these Fe oxide structures and the sorption of $U$ on these newly formed minerals may occur during such cycles. However, little information exists on the structural incorporation of $U$ into Fe oxides upon crystallization or the amount of $U$ that can be doped into naturally occurring $\mathrm{Fe}$ oxide mineral host phases. In nature, elevated levels of $U$ [mostly as uranyl] are observed in amorphous $\mathrm{Si} / \mathrm{Al} / \mathrm{Fe}$ oxide gels isolated from $\mathrm{U}$ ore bodies (ALLARD et al., 1999). Furthermore, these co-precipitates may be difficult to quantify by traditional wet chemical and spectroscopic techniques and be overlooked. For example, the co-precipitates may be amorphous and not sensitive to X-ray diffraction (XRD) or their high Fe contents may cause hyper-quenching of the U(VI) luminescence.

Wet chemical evaluation methods are commonly used to study $U$ behavior in complex natural materials. For example, selective and sequential extractions (BATSON et al., 1996; CLARK et al., 1996; MILLER et al., 1986) require the stepwise addition of reagent chemicals that remove (i.e., dissolve) operationally-defined components in soils and sediments and the subsequent analytical quantification of the dissolved (leached) elements of interest post equilibration. One example is the use of concentrated oxalate solutions to remove amorphous $\mathrm{Fe}$ 
phases (MILLER et al., 1986; CHAO and ZHOU, 1983). Extraction methods can also focus on the oxidation state speciation of the U. For example, concentrated carbonate solutions have been used to extract solid and solution U(VI) species from sediments and from flocs of U-reducing microbes (FREDRICKSON et al., 2000; DUFF et al., 1999).

The speciation and bonding environment of $U$ in soil, sediment, and clay minerals has been examined with a variety of spectroscopic techniques such as FT-infrared (FT-IR), FT-Raman, time-resolved luminescence, X-ray photoelectron and X-ray diffraction (XRD) (BURNS et al., 1997; BARGAR et al., 1999; CEJKA, 1999 and references therein; HANCHAR, 1999 and references therein; BUCK et al., 1996; MORRIS et al., 1996; CHISHOLM-BRAUSE et al., 1994; WERSIN et al., 1994; BIWER et al., 1990; HO and MILLER, 1986). Synchrotron-based techniques such as extended X-ray absorption fine-structure (EXAFS) and X-ray absorption near-edge structure (XANES) have been used to determine the identification, location and number of atoms in the local structural environment and the oxidation state of $U$ within a variety of environmentally relevant media (MOYES et al., 2000; DUFF et al., 2000; 1997; BARGAR et al., 1999; DENECKE et al., 1998; THOMPSON et al., 1997; BURNS et al., 1997; ALLEN et al., 1996; MORRIS et al., 1996; BERTSCH et al., 1994; WAITE et al., 1994; WERSIN et al., 1994; DENT et al., 1992; FARGES et al., 1992).

We will present data on prepared synthetic U(VI)-rich Fe-oxide co-precipitates. These studies were performed to obtain fundamental geochemical information on the behavior of the $\mathrm{U}$ in Fe oxides and the processes that could occur in $\mathrm{U}$ contaminated Fe-oxide rich environments that have undergone considerable aging. We accelerated the aging process for $\mathrm{Fe}$ oxides by making the solids in basic solutions and curing them at $60{ }^{\circ} \mathrm{C}$ for several weeks. The solids were characterized with wet chemical methods and spectroscopic techniques (XRD, XANES, EXAFS, FT-IR and luminescence).

\section{MATERIALS AND METHODS}

\section{Preparation of Co-precipitates}

A series of solutions for co-precipitation ranging from a maximum 0.5 to $5 \mathrm{~mol} \% \mathrm{U}$ vs. $\mathrm{Fe}$ were prepared at $25{ }^{\circ} \mathrm{C}$ (TABLE 1). The co-precipitation procedure followed below was outlined in FORD et al. (1999). Twenty $\mathrm{mL}$ of $0.1 \mathrm{M} \mathrm{Fe}\left(\mathrm{NO}_{3}\right)_{3}, 140 \mathrm{~mL}$ of $0.1 \mathrm{M} \mathrm{NaNO}_{3}$, and $20 \mathrm{~mL}$ of either $0.5 \mathrm{mM}$ or $5 \mathrm{mM} \mathrm{U}(\mathrm{VI})$ solution [made from $\mathrm{UO}_{2}\left(\mathrm{NO}_{3}\right)_{2} \cdot 6 \mathrm{H}_{2} \mathrm{O}_{(\mathrm{s})}($ Merck)] were 
added to a $200 \mathrm{~mL}$ high density polyethylene bottle. The solutions (initially at $\mathrm{pH} \sim 3$ ) were titrated with drop-wise additions while stirring slowly to $\mathrm{pH} \sim 7$, with concentrated $\mathrm{NaOH}$ that had been purged with ultra high purity (UHP) $\mathrm{N}_{2(\mathrm{~g})}$ to reduce the amount of $\mathrm{CO}_{2(\mathrm{~s})}$ incorporation. The solutions were held for two hours, then titrated to $\mathrm{pH} \sim 11$. The solution volumes were increased to $200 \mathrm{~mL}$ with $0.1 \mathrm{M} \mathrm{NaNO}_{3}$ and held for an additional 1.5 hours. No efforts were made to keep the ionic strength of the solutions constant during the syntheses and the solution suspensions were constantly purged with UHP $\mathrm{N}_{2(\mathrm{~g})}$. After the 1.5 hours, the solutions were aged in a $70^{\circ} \mathrm{C}$ oven for 1 or 25 days. After aging, samples were dialyzed in 10,000 molecular weight cutoff sleeves with UHP water until the water conductivity no longer increased and the dialyzed samples were then dried in a $60{ }^{\circ} \mathrm{C}$ oven. Sub-samples of the dried samples were digested in concentrated trace metal grade (TMG) $\mathrm{HCl}$ according to the modified methods of FRANCIS and DODGE (1990) and sub-samples of the solids were taken for spectroscopic analyses. The $U$ and Fe contents in the digest solutions were determined by inductively-coupled plasma mass spectrometry (ICP-MS, Perkin-Elmer Instruments). The mol \% U vs. Fe in each sample was determined (SCHWERTMANN and CORNELL, 1991).

Extractions with solutions of concentrated carbonate $\left[0.5 \mathrm{M}\left(\mathrm{NH}_{4}\right)_{2} \mathrm{CO}_{3}\right]$ and oxalate $[0.175$ $\mathrm{M}\left(\mathrm{NH}_{4}\right)_{2} \mathrm{C}_{2} \mathrm{O}_{4}+0.1 \mathrm{M} \mathrm{H}_{2} \mathrm{C}_{2} \mathrm{O}_{4}, \mathrm{pH} \sim 3$, in the dark] each at a ratio of $1 \mathrm{~g}: 40 \mathrm{~mL}$ were conducted on the synthetic U-containing Fe solids (SCHWERTMANN and CORNELL, 1991; CHAO and ZHOU, 1983; DUFF et al., 1997; FREDRICKSON et al., 2000). Extractions of the U-containing Fe solids were performed in plastic micro-centrifuge tubes. The samples were shaken on a mechanical shaker for 24 hours after addition of extractant, centrifuged at 14,000 rpm for 10 minutes, washed with water, shaken for 10 minutes, centrifuged again, and washed one more time with UHP water before centrifuging for 20 minutes at 14,000 rpm. After extracting and washing the solids, a sub-sample was taken for spectroscopic studies and the remaining solids were digested with $\mathrm{TMG} \mathrm{HCl}$. The $\mathrm{U}$ and $\mathrm{Fe}$ concentrations in the digest solutions were determined by ICP-MS and the mol \% of U incorporated into the Fe oxides was calculated. Detection limits for dissolved $U$ and Fe were $0.001 \mu \mathrm{g} \mathrm{U} \mathrm{L}{ }^{-1}$ and $0.1 \mathrm{mg} \mathrm{Fe} \mathrm{L}^{-1}$. A synthetic meta-schoepite $\left[\mathrm{UO}_{2}(\mathrm{OH})_{2} \cdot 2 \mathrm{H}_{2} \mathrm{O}\right]$ sample was provided by A. G. Sowder (SREL) for the spectroscopic studies.

\section{X-Ray Diffraction Measurements}

XRD analyses were performed on a Scintag X2 XGEN-4000 X-Ray diffractometer (Cupertino, $\mathrm{CA}$ ) with a $\mathrm{Cu} \mathrm{K} \alpha$ excitation source. Wet sub-samples were mounted as slurries on 
WSRC-MS-2002-00322

filters and allowed to dry at $50{ }^{\circ} \mathrm{C}$, whereas dried minerals were ground and placed in a quartz sample mount with a small diameter hole $(\sim 4 \mathrm{~mm})$. The U Fe-oxide sample mounts were prepared by smearing an acetone suspension of the samples onto glass slides. Data points were obtained every $0.02^{\circ} 2 \theta$ at a rate of $0.3^{\circ} 2 \theta \min ^{-1}$ from 10 to $85^{\circ} 2 \theta$.

\section{FT-IR Spectroscopic Studies}

For the FT-IR studies, all spectra were acquired with a Nicolet Magna IR 860 (Madison, WI) using a DTGS KBr detector. The wavenumber range was 4000 to $350 \mathrm{~cm}^{-1}$, and each spectrum consisted of 1028 scans, resolution was $2 \mathrm{~cm}^{-1}$, and wavenumber accuracy was $\pm 1 \mathrm{~cm}^{-}$

1. About $20 \mu \mathrm{g}$ of finely ground solid samples were ground and mixed with $\sim 12 \mathrm{mg}$ IR grade $\mathrm{KBr}$ and pressed into a 3-mm diameter pellet using paper inserts (Spectra-Tech, Shelton, CT, USA). Fringe patterns indicate the path length of these pellets was $\sim 0.35 \mathrm{~mm}$.

\section{Room Temperature Micro-Fluorescence Spectroscopy}

Fluorescence spectra were collected using an inverted Nikon Diaphot fluorescence microscope using a $\mathrm{Hg}$ lamp excitation source to provide excitation wavelengths between 330 and $380 \mathrm{~nm}$ (HUNTER and BERTSCH, 1998). Samples were mounted on glass coverslips over a 40x objective. An Acton ARC-spectrometer with a grating of 300 grooves $\mathrm{mm}^{-1}$ was interfaced to the microscope camera port. Spectra were collected with a 1024 by 1024 pixel liquid $\mathrm{N}_{2}$-cooled CCD camera (Princeton Scientific Instruments, Monmouth Junction, NJ). The emission wavelengths detected by the camera were higher than $420 \mathrm{~nm}$. A mirror in the place of the grating permitted images and spectra to be alternately acquired on the same sample. With a $40 \mathrm{x}$ objective, a spatial resolution of $0.59 \mu \mathrm{m} \mathrm{pixel}^{-1}$ on the $\mathrm{CCD}$ was achieved.

\section{Scanning Electron Microscopy}

The SEM images were obtained with the Leo 982 Field Emission SEM (Leo Electron Microscopy, Thornwood, NY). Samples were mounted by dusting them on adhesive on carbon discs. No further sample preparation, such as coating with a conductive surface, was necessary to prevent excessive charging. All images were acquired at $20 \mathrm{keV}$ at a working distance of $11 \mathrm{~mm}$. The beam size is reported to be less than $3 \mathrm{~nm}$ (LERCEL et. al 1996) with a resolution of $1.2 \mathrm{~nm}$ at $20 \mathrm{keV}$. Back-scattered electron (BSE) images were taken in addition to secondary electron (SE) images in order to highlight areas with significantly different densities. Energy 
WSRC-MS-2002-00322

dispersive X-ray (EDX) spectroscopy was used to confirm the elemental composition for regions of interest.

\section{Uranium XANES Measurements}

The U-rich Fe oxide solids were analyzed for $U$ oxidation state in the solid phase directly using the X-ray microprobe beamline X26A at the National Synchrotron Light Source (Brookhaven National Laboratory, Upton, NY, USA). At X26A, microfocusing optics including a double elliptical Rh- coated Kirkpatrick-Baez mirror system operated at a pitch of 5 mrad was used to focus a $350 \mu^{2}$ monochromatic beam at the $\mathrm{U} \mathrm{L}_{3}$ absorption edge $(17,166 \mathrm{eV})$ down to $15 \mu \mathrm{m}^{2}$ beam, resulting in a total flux of about $10^{10}$ photons $\mathrm{s}^{-1}$ (SMITH and RIVERS, 1995; ENG et al., 1995; YANG et al., 1995). A Si(Li) energy dispersive detector having an area of 30 $\mathrm{mm}^{2}$, was mounted at $90^{\circ}$ with respect to the beam. The detector was positioned 2 to $3 \mathrm{~cm}$ from the sample and used to monitor and collect U L $\alpha$ fluorescence X-rays. Collection time was determined with a monochromator that was tuned $20 \mathrm{eV}$ above the $\mathrm{U} \mathrm{L}_{3}$ edge and the count rate was observed with the $\mathrm{Si}(\mathrm{Li})$ detector. The XANES spectra were acquired at 0.3 to $2.5 \mathrm{eV}$ step intervals over a $170 \mathrm{eV}$ range, which was relative to $17.166 \mathrm{keV}$. Scan limits were $50 \mathrm{eV}$ less than and $120 \mathrm{eV}$ greater than the $\mathrm{U} \mathrm{L}_{3}$ absorption edge.

Standards consisted of $\mathrm{U}(\mathrm{IV}) \mathrm{O}_{2(\mathrm{~s})}, \mathrm{U}(\mathrm{VI}) \mathrm{O}_{2}\left(\mathrm{NO}_{3}\right)_{2} \cdot 6 \mathrm{H}_{2} \mathrm{O}$ (Aldrich Chemical) and synthetic characterized meta-schoepite. The $\mathrm{U} \mathrm{L}_{3}$-edge XANES energies were defined as the height of the edge step and the edge energy values were calibrated to be $0 \mathrm{eV}$ with the $\mathrm{UO}_{2(\mathrm{~s})}$ standard and were monitored with $\mathrm{UO}_{2(\mathrm{~s})}$ before and after each sample. An increase with respect to the relative energy indicates an increase in the average $U$ oxidation state in the sample or standard of interest (BERTSCH et al., 1994).

\section{Uranium EXAFS Measurements}

The EXAFS data were collected at the $\mathrm{U} \mathrm{L}_{3}$-edge on a select group of the solids and using beamline X23a2 at the NSLS. The EXAFS data were collected in fluorescence mode using an unfocussed X-ray beam and a fixed-exit $\mathrm{Si}(311)$ monochromator. Ion chambers were used to collect incident (Io), transmission (It) and references (Ir) signals with 100\% Ar. A standard Lytle detector was used to collect fluorescence X-rays (If), using a $\mathrm{SrCO}_{3}$ filter to reduce the background from scattering and $\mathrm{Al}$ foil to reduce the background fluorescence counts. The 
monochromator energy (i.e., photon flux) was maximized using a piezo stack feedback energy stabilization system, with a settling time of 0.3 seconds per change in monochromatic energy. An X-ray beam size of 2 by $18 \mathrm{~mm}^{2}$ was used. Beamline energy calibration was done using foils of $\mathrm{Pt}\left(\mathrm{L}_{1}\right.$-edge at 13,880 eV), $\mathrm{Zr}$ (K-edge at 17,998 eV), and Mo (K-edge at 20,000 eV). The UEXAFS spectra were acquired at 0.3 to $2.5 \mathrm{eV}$ step intervals over a $960 \mathrm{eV}$ range, which was relative to $17.166 \mathrm{keV}$. Scan limits were $120 \mathrm{eV}$ less than and $740 \mathrm{eV}$ greater than the $\mathrm{U} \mathrm{L}_{3}$ absorption edge.

\section{EXAFS Data Analyses}

The background contribution to the EXAFS spectra was removed using AUTOBK, a program developed by NEWVILLE et al. (1993) that minimizes R-space values in low $k$-space. Each chi data set was read into the WINXAS analysis package (version 1.3, RESSLER, 1999). Replicate chi data sets were co-added to improve $\mathrm{S} / \mathrm{N}$. After background subtraction and normalization, the XANES spectra were compared with spectra from available U standards and from the literature. For the samples and reference materials, the EXAFS spectra were analyzed

from 2 to $14 \AA^{-1}$. The $k^{2}$-weighted chi data were Fourier-transformed to yield R-space or pseudo Radial Distribution Function (RDF) plots as in SAYERS and BUNKER (1988). A amplitude reduction factor of 0.9 was used, which is within the range ( 0.8 to 1.0$)$ typically used for $U$ (BARGAR et al., 2000; THOMPSON et al., 1997; ALLEN et al., 1996). Simulated EXAFS spectra were also generated based on the documented crystallographic properties for $U$ in schoepite (FINCH et al., 1997) using ab initio based theory, using FEFF 7.2 (MUSTRE de LEON et al., 1991; REHR et al., 1991; 1992; REHR and ALBERS, 1990; STERN et al., 1995).

\section{RESULTS AND DISCUSSION}

\section{Wet Chemical Characterization of the U-rich Fe Oxide Phases}

The results of the total digestions of the solids indicate that the $U$ concentrations in the solids ranges from 0.35 to $5.4 \mathrm{~mol} \% \mathrm{U}$ versus Fe with total wt \% $\mathrm{U}$ ranging from 1.2 to 12.4 
(TABLE 1). This wet chemical data does not provide information on what amount of $U$ is precipitated, sorbed or co-precipitated with amorphous Fe oxide and Fe oxyhydroxide phases. However, this information can be obtained by a series of leaching solutions that are selective for $\mathrm{U}$ in these specific domains.

Uranium has a propensity to form soluble $\mathrm{U}(\mathrm{VI})$-carbonate species [such as $\mathrm{UO}_{2}\left(\mathrm{CO}_{3}\right)_{2}{ }^{2-}$ and $\left.\mathrm{UO}_{2}\left(\mathrm{CO}_{3}\right)_{3}{ }^{4}\right]$ in concentrated carbonate solutions that are used for extracting $\mathrm{U}(\mathrm{VI})$ from geologic media (FREDRICKSON et al., 2000; DUFF et al., 1998; 1997) and these solutions are likely to desorb surface-associated U species and to dissolve soluble U(VI) minerals such as meta-schoepite (as in MASON et al., 1996) and the uranates (GRIFFITHS and VOLKOVICH, 1999 and references therein). Because Fe(III)-dominated oxides are poorly soluble in carbonate solutions, leaching with carbonate is unlikely to remove $\mathrm{U}(\mathrm{VI})$ that is bound within the Fe oxide structure or occluded by Fe oxides. On average, the leaching of these solids with concentrated carbonate solutions removes all but $0.59 \pm 0.16 \mathrm{~mol} \% \mathrm{U}$ versus Fe (95\% confidence interval) from the co-precipitates (TABLE 1). No detectable Fe exists in the leaching solutions post equilibration.

Oxalate leaching with the commonly known Tamm's reagent is widely applied in geochemical exploration, clay mineralogy, soil genesis and soil taxonomy studies for the quantification of amorphous $\mathrm{Fe}$ in natural soil and geologic samples (as explained in $\mathrm{CHAO}$ and ZHOU, 1983). Any amorphous $\mathrm{Fe}$ in these materials should also dissolve in concentrated oxalate solutions, leaving the crystalline Fe oxide phases intact. This procedure is applied to the extraction of contaminant metals that are co-associated with amorphous Fe phases in soils (MILLER et al., 1986). However, U(VI) forms soluble complexes with oxalate [such as $\mathrm{UO}_{2}\left(\mathrm{C}_{2} \mathrm{O}_{4}\right)_{2}{ }^{2-}$ and $\mathrm{UO}_{2}\left(\mathrm{C}_{2} \mathrm{O}_{4}\right)_{3}{ }^{4-}$ ] (RAZIK, 1989; ERTEN et al., 1994 and references therein) and if present in excess, this leaching solution is likely to remove surface sorbed $\mathrm{U}(\mathrm{VI})$, precipitated $\mathrm{U}(\mathrm{VI})$, and U(VI) that is associated with amorphous Fe (MILLER et al., 1986; CHAO and ZHOU, 1983).

As with the carbonate leaching, similar results are observed with the oxalate leaching (TABLE 1) and little detectable Fe is present in the oxalate solutions after equilibration (less than a few $\mathrm{mg} \mathrm{Fe} \mathrm{kg}^{-1}$ ), indicating the amount of amorphous $\mathrm{Fe}$ in the co-precipitates is low relative to that of the crystalline Fe phases. However, some $\mathrm{U}$ is removed by the leaching solution, most likely by complexation with oxalate (TABLE 1). This is evidenced by the decrease in the mol \% $\mathrm{U}$ values after leaching relative to those observed prior to leaching. 
XRD Characterization of $U$-rich Fe Oxide Phases in the Precipitates

The XRD diffraction results indicate that the Fe oxide co-precipitates are rich in hematite (FIG. 2). Solids that formed in solutions with high initial U concentrations that contains the diffraction peaks, the most diagnostic of the (002) reflection for meta-schoepite which is at about $12^{\circ} 2 \theta$. Spectrum simulations using the XRD software were performed. When meta-schoepite (JCPDS 43-0364) and hematite (JCPDS 79-1741) are combined weighted $44 \%$ and $56 \%$, respectively, the spectrum is essentially identical to FeU1 (3.5 mol \% U). The XRD studies indicate that high (added) $\mathrm{U}$ levels preclude the formation of goethite and favor hematite as the predominant Fe phase in the co-precipitates (FIG. 2). The XRD spectra for the Fe-U solids that are made from solutions with low added $U$ concentrations do not contain schoepite or any other U phase that we can identify (FIG. 2). Clearly, the crystalline minerals in these solids are predominantly hematite.

No shift in peak positions dependent upon added $\mathrm{U}$ concentration was apparent. For instance, when NAGANO et al. (1999) added $\mathrm{Nd}^{3+}$ to ferrihydrite, the addition caused the $\sim 40^{\circ} 2 \theta$ peak (110 ferrihydrite peak) to decrease to $\sim 38^{\circ} 2 \theta$. Our XRD data showed no shift in the hematite (110) peak upon U addition. Synthetic Fe oxides range in no particular order from 35.42 to $35.86^{\circ} 2 \theta$ for the (110) hematite peak, where pure hematite has a peak at $35.68^{\circ} 2 \theta$. No internal standard was used in these spectra.

\section{FT-IR Studies}

FT-IR spectroscopy techniques give qualitative information on the speciation of $\mathrm{Fe}$ oxides in the samples such as goethite and hematite. An example of the FT-IR spectra that we obtained for samples with low and high mol \% U values is shown in FIG. 3. For goethite, the prominent peaks are 890 and $796 \mathrm{~cm}^{-1}$ and the position of the former peak can be altered by the substitution of metals (SCHWERTMANN and CORNELL, 1991). However, this former peak for goethite does not move to a different frequency in all but one of the samples (TABLE 1), suggesting that the small amount of goethite in the samples probably do not have structural U(VI). For samples of $\sim 3.4 \mathrm{~mol} \% \mathrm{U}$ and higher, the goethite peaks are absent (TABLE 1). Additionally, the FT-IR spectra for the solids do not contain stretches indicative of carbonate (which is highly IR active 
and normally at $875 \mathrm{~cm}^{-1}$, NYQUIST and KAGEL, 1997) —indicating the prepared solids are carbonate-free.

Although trace amounts of goethite are detectable in the FT-IR spectra (at 890 and $796 \mathrm{~cm}^{-1}$ ) (TABLE 1), the presence of large intense vibrations at $475 \mathrm{~cm}^{-1}$ (FeO bend) and at $560 \mathrm{~cm}^{-1}$ (FeO stretch) for hematite and the absence of peaks from other spectrally active Fe oxides in the IR region suggest that hematite is the predominant Fe oxide phase in the solids. Enhancement of hematite formation over goethite is been observed with the addition of other metals such as $\mathrm{Ni}$ and $\mathrm{Pb}$ (FORD et al., 1999). In summary, the FT-IR studies of Fe oxide samples (TABLE 1) confirm the observations from the XRD studies.

Iron oxide samples with high $\mathrm{U}$ mol \% also exhibits uranyl-indicative peaks, typically in the range of 1000 to $850 \mathrm{~cm}^{-1}$ [ $v_{3}$, (CEJKA, 1999 and references therein; SOBRY, 1973)] (TABLE 1; FIG. 3). However, the frequency of these peaks is known to shift to lower frequencies under certain conditions such as for uranyl-containing solids with high stoichiometric $\mathrm{Na}$ to $\mathrm{U}$ ratios (e.g., clarkieite, CEJKA, 1999, and references therein). FT-IR studies with schoepite-containing solids from aqueous suspensions that have been equilibrated at $\mathrm{pH}$ values of 7, 9 and 11, show that the $v_{3}$ peak, which is associated with the asymmetric stretch of the linear $[\mathrm{O}=\mathrm{U}=\mathrm{O}]^{2+}$ group moves to a lower frequency of vibration at high $\mathrm{pH}$ conditions (from $910 \mathrm{~cm}^{-1}$ to $865 \mathrm{~cm}^{-1}$ ) (ALLEN et al., 1996). Uranium-EXAFS studies with these high $\mathrm{pH}$ samples indicated that the uranyl group O's in these systems may have been located at longer radial distances than that of the $\mathrm{U}$ in suspensions that were equilibrated at lower $\mathrm{pH}$ values and that bridging of the equatorial O's may have occurred (ALLEN et al., 1996, and references therein; see TABLE 1). [Other peaks such as those between 600 and $400 \mathrm{~cm}^{-1}$ also exist in the IR spectra for our schoepite reference (TABLE 1) — as is consistent with those observed by ALLEN et al. (1996).]

These FT-IR data suggest that beyond a point of saturation in the Fe oxides, uranyl precipitates as a discrete schoepite-like phase. This is supported by the spectra acquired after carbonate leaching, which greatly decreases or removes the uranyl peaks in the samples most concentrated in $\mathrm{U}$. A discrete schoepite-like phase is also reflected in the trends observed in the XRD data. Samples with the uranyl diffraction peak at about $12^{\circ} 2 \theta$ also exhibited the schoepite peak at $\sim 930 \mathrm{~cm}^{-1}$ in the FT-IR studies (TABLE 1).

Two samples were prepared at low U/Fe mol \% concentrations (near $1 \mathrm{~mol} \% \mathrm{U}$ ) and leached with oxalate to determine if the $U$ was associated with amorphous Fe (TABLE 1). 
Leaching with oxalate did not remove the $\mathrm{U}$ and the leach solutions contained nearly undetectable levels of Fe. These low levels indicate that the amorphous Fe concentrations in these samples were below $1 \%$ of the total Fe. The FT-IR analyses of these samples before and after leaching indicate that no uranyl behavior exists in these samples and that leaching removes some of the peaks that are indicative of goethite, which are very weak (TABLE 1).

\section{Room Temperature Micro-Luminescence Spectroscopy}

Schoepite is uranyl-rich and fluoresces strongly and characteristically between 500 to 600 $\mathrm{nm}$ at room and low temperature (DUFF et al., 2000; HUNTER and BERTSCH, 1998; MORRIS et al., 1996). However, U(VI)-containing uranate solids fluoresce much more so at low temperature than at room temperature (AZENHA et al., 1992). In contrast, the U(IV) species are poorly luminescent. Although Fe can quench the fluorescence of U(VI) (KOCHAN and SHUKTOMOVA, 1990 and references therein), the U concentrations on the surface of the coprecipitates with high U loadings are high enough to fluoresce (FIG. 4a and b). The spectrum of the FeU21 sample with $5.4 \mathrm{~mol} \% \mathrm{U}$ closely correlates to that of meta-schoepite. Under the optical objective glowing particles at less than the limit of $0.5-\mu \mathrm{m}$ optical resolution are observed. We attribute these as discrete uranyl phases. In contrast, the FeU22 sample with 0.68 mol \% U shows no optical evidence of a discrete uranyl phase, and its spectrum is featureless above the background. These data provide further evidence that the $\mathrm{U}$ in the FeU22 sample has a different local structural environment than the $\mathrm{U}$ the samples with a high mol $\% \mathrm{U}$, which most likely contain both uranyl and non-uranyl hexavalent $U$.

\section{Scanning Electron Microscopy Studies}

The SE and BSE images taken during the SEM studies in FIG. 5a-f showed that the solids typically have different micro-morphologies, which are most readily distinguishable in the BSE images (FIG. 5b,d and e). The BSE images for the hematite sample (without U) do not exhibit the platy to spheroidal bodies that were observed in the sample with $5.4 \mathrm{~mol} \% \mathrm{U}$ (sample FeU21). These types of samples with high U loadings have a large degree of heterogeneity and EDX analyses (data not shown) indicate that the lighter colored bodies in FIG. 5d are rich in U. The unleached samples with low $\mathrm{U}$ concentrations (such as FeU22 with $0.68 \mathrm{~mol} \% \mathrm{U}$ ) do not have these features. The BSE images for these samples were representative of a fairly 
homogeneous material and the corresponding EDX data (data not shown) indicate the material is homogeneous with respect to the U to Fe content (FIG. 5f).

The SEM-EDX imaging technique is sensitive to total elemental concentrations and not speciation. In contrast, the images obtained from the luminescence studies with these samples were sensitive to U(VI) present as "uranyl". The luminescence imaging does not have nearly the same spatial resolution as the SEM-EDX imaging. However, both techniques indicate different physical morphologies exist between samples with low mol \% U and samples with much higher U loadings.

\section{Uranium XANES Studies}

The XANES absorption edge energy increases with increasing average oxidation state, which is thought to be due to a decreased shielding of the core electrons in the nucleus. This increase in core level binding energy is manifested by shifts in the pre-edge and bound-state edge features of the XANES spectrum. These features in the absorption edge can be attributed to differences in the valence of the cationic center. Post-edge features or multiple scattering resonance features (MSRs) in the $\mathrm{U} \mathrm{L}_{3}$-edge XANES spectra have been associated with the bonding geometry and coordination of the central $U$ atom (DENECKE et al., 1998; FARGES et al., 1992). One of these MSR features, a "shoulder", which is present on the high-energy side of the main absorption edge has been attributed to the presence of axial $\mathrm{O}$ bonds (TEMPLETON and TEMPLETON, 1982; HUDSON et al., 1995). At higher energy, the position of select post edge oscillations has also been used to extrapolate equatorial bond length values for U(VI) species (DENECKE et al., 1998).

A plot of the XANES spectra for the Fe-U co-precipitates is shown in FIG. 6. The UXANES studies determined that the $U$ absorption edge energy in all of the samples is consistent with a $\sim+4 \mathrm{eV}$ shift relative to that of the $\mathrm{U}(\mathrm{IV}) \mathrm{O}_{2(\mathrm{~s})}$ standard (FIG. 6). These data indicate the average oxidation state of the $\mathrm{U}$ in the precipitates is $\mathrm{U}(\mathrm{VI})$. This discounts the possibility that the dissolved U(VI) initially added was reduced to U(IV) during Fe oxide synthesis. Reduction of U(VI) to U(IV) was not expected because the Fe form added was rich in Fe(III) and dissolved $\mathrm{Fe}(\mathrm{II})$ is not highly stable in oxidized solutions. Based on the FT-IR and luminescence studies, one could conclude the U speciation is U(IV) because of the absence of the asymmetric $v_{3}$ stretch and the absence of luminescent U forms (FIGS. 3 and 4). 
The MSR feature, that is characteristic for most U(VI) species (i.e., the shoulder feature) on the high-energy side of the white-line is nearly non-existent in the spectra for the samples FeU2 and FeU22. The general MSR features that occur on the high energy side of the shoulder feature, which are common to U(VI) and U(IV) are also nearly absent. These data indicate that there may be a considerable amount of destructive interference in the local environment of the $U$, which could explain the absence of MSR features in the post edge region. These data indicate that the sample is rich in U(VI), but these spectroscopic studies do not characterize the local environment of the U(VI). The spectra for U(VI) nitrate did contain the MSR features that are typically observed for U(VI)-containing materials. The absence of the MSR features in the XANES spectra for samples FeU2 and FeU22 (FIG. 6) does suggest that there are no uranyl (i.e., U with two axial U-O bonds) groups present in these materials. The following information will provide insight as to the structure of the $U$ in the Fe oxide co-precipitates.

\section{Uranium EXAFS Studies}

If the $U$ in our samples with low mol \% U values were incorporated in to the Fe oxides with a highly distorted environment, one would not expect the $U$ to possess long range structural order. Collectively, our XRD, FT-IR, XANES and luminescence studies suggest the local structural environment of the $U$ is atypical for $U(V I)$ in natural geologic samples and in most laboratory-synthesized samples. The local environment of the $U$ can be characterized with extended X-ray absorption fine-structure (EXAFS) spectroscopic methods, which do not require that the sample have long range structural order. The EXAFS techniques provide average radial distance values for atoms around the element of interest and these methods can be used to characterize distorted and amorphous environments. Most traditional X-ray diffraction techniques are not suitable for the characterization of samples containing distorted or amorphous materials.

To obtain information on the local structural environment of the $U$ in the solids, $U_{L_{3}}$-edge EXAFS spectroscopic analyses were performed on the unleached Fe oxide solids with loadings $<1 \mathrm{~mol} \% \mathrm{U}$ and for solids which had as high a $5.4 \mathrm{~mol} \% \mathrm{U}$. The $k^{2}$-weighted chi data for $\mathrm{U}$ in the unleached sample FeU22 with $0.68 \mathrm{~mol} \% \mathrm{U}$ is shown in FIG. 7a. The chi spectra have two primary envelopes, which appear to be representative of light and heavy back-scattering atoms. The Fourier-transformed (FT) chi data and multiple shell fits performed in R-space are shown in FIG. 7b. The fits indicate that there are no axial $\mathrm{O}$ atoms at distances between 1.7 to $1.9 \AA$ in 
the first coordination shell of the U(VI) and that Fe is present in the second shell. The fits indicate that there are about four first shell $\mathrm{O}$ atoms with distances of $2.21 \AA$ and $2.36 \AA$ (FIG. 7b), which are too long to be the dioxo U-O double bonds that are consistent with the uranyl ion group (BURNS, 1999 and references therein). The model fits also indicate that at least one Fe atom exists in the second coordination shell of the $U$ at a distance of $3.19 \AA$. The imaginary component of the FT does not peak with the real component of the transform in the fits (FIG. 7b). This suggests that there are multiple shell environments, which contribute to destructive interference in the EXAFS. Destructive interference is likely to result in a lower than actual coordination number for the second shell Fe. [Destructive interference was also observed in the XANES spectra as previously discussed (FIG. 6).]

The XAFS studies with unleached solids at loadings $<1 \mathrm{~mol} \% \mathrm{U}$ indicate that $\mathrm{U}(\mathrm{VI})$ is incorporated in the Fe oxides. Due to the size of $\mathrm{UO}_{2}{ }^{2+}(\sim 1.80 \AA)$ relative to that of $\mathrm{Fe}^{3+}(0.65$ $\AA$ ), $\mathrm{UO}_{2}{ }^{2+}$ is unlikely to be structurally incorporated into Fe oxides (SHANNON, 1976). However, its effective ionic radii of approximately 0.62 to $0.73 \AA$ (depending on coordination number) apparently allows U(VI) incorporation into the structure (SHANNON, 1976). Longer U-O bond lengths (FIG. 7) indicate the loss of uranyl behavior as the U enters the Fe-oxide structure as the U(VI) ion rather than the uranyl ion.

The U EXAFS spectra that were collected for U-Fe co-precipitates with higher U mol ratios (greater than $1 \mathrm{~mol} \% \mathrm{U}$ ) exhibit uranyl behavior and evidence of a second shell $\mathrm{U}$ back scatterer (data not shown). The U EXAFS data analyses indicate uranyl species predominate at high $\mathrm{U}$ loadings (data not shown), which is consistent with the FT-IR, XRD and luminescence data (FIGS. 2-5) that show evidence of a U(VI) oxide hydrate phase (schoepite).

BLAKE et al. (1966) elucidated the existence of distorted Fe octahedra in the hematite structure. Hematite consists of face-sharing pairs of Fe octahedra, which results in a small distortion in the octahedra and there are three different Fe-Fe second shell radial distances of 2.90 (1), 2.97 (3) and $3.36 \AA$ (3). Our molecular modeling indicates that $U$ can be associated with distorted Fe octahedra with a distance as short as $3.0 \AA$ (FIG. 8). The EXAFS analyses support the association of $U$ with distorted Fe octahedra in a geometry that has a U-Fe radial distance of $3.19 \AA$ (FIG. 8). The U-Fe radial distance we observe is shorter than that observed for sorbed U(VI) on edges of Fe octahedra [BARGAR et al., (2000); MOYES et al., (2000); WAITE et al., (1994)]. These researchers obtained radial distances for Fe neighbors between 3.4 and $3.68 \AA$, which are considerably longer distances than $3.19 \AA$. Our shorter radial distances 
indicate that the $U$ is not sorbed and is probably in a different coordination environment than that of sorbed U(VI). Our model also supports the assignment of first shell U-O radial distances that are consistent with that of the U EXAFS analyses (FIG. 7B). The U(VI) may also reside in the hematite interstices.

Use of Selective Extractions and Leaching Solutions to Characterize U Geochemical Behavior

Carbonate leaching removes sorbed U and solid phase U(VI) that exist with a uranyl environment but it did not remove co-precipitated U(VI) that is within a uranate environment. Uranium in solids with less than $1 \mathrm{~mol} \% \mathrm{U}$ is not completely removed by carbonate because the $\mathrm{U}$ is co-precipitated with the Fe oxides and unavailable to the carbonate leaching. Little $\mathrm{U}$ in the co-precipitates with less than $1 \mathrm{~mol} \% \mathrm{U}$ is extractable with oxalate. However, these synthetic solids have initial $U$ concentrations that are in the range typically observed for the Feoxide solids that contained structurally incorporated $U$ so little $U$ is likely to be leached by oxalate ion. A small percent of the $U$ in these solids is leached by oxalate and this form is probably sorbed $U$. These studies indicate that despite the excess of concentrated leaching solution, some forms of $U$ are not available for removal by these leaches.

\section{Implications of Findings to the Geologic Environment}

Uranium has a high affinity for Fe-oxide minerals. In the geologic environment, which is often rich in Fe oxides, $U$ may first sorb to Fe oxides. Then as the Fe oxides undergo weathering and microbial interactions, the Fe oxides may undergo reductive dissolution [conversion of Fe(III) species to more soluble Fe(II) species, [e.g., FREDRICKSON et al., (2000)] followed by re-oxidation to $\mathrm{Fe}(\mathrm{III})$ and precipitation. During these mineral formation processes, $\mathrm{U}$ could become incorporated with the Fe oxides over long periods of time. As for any U(VI) that reduced to $\mathrm{U}(\mathrm{IV})$ during the reductive dissolution of the Fe(III) oxides, it would oxidize to U(VI) upon exposure to the natural conditions that favored oxidation of $\mathrm{Fe}$ (II) to $\mathrm{Fe}(\mathrm{III})$ and precipitation as Fe-oxide minerals (DUFF et al., 1997; 1999 and references therein), much as is observed with some ore deposits of $U$ in geologic materials (PEARCY et al., 1994).

Uranium sorption and co-precipitation processes with Fe minerals are studied in lieu of repository assessment, nuclear waste treatment and U biogeochemistry (MOYES et al., 2000; OHNUKI et al., 1997; PLOTNIKOV and BANNYKH, 1997; SATO et al., 1997; HOBBS and KARRAKER, 1996; BRUNO et al., 1995; PEARCY et al., 1994; WAITE et al., 1994 and many 
others). As part of the Poços de Caldas natural analogue study (Brazil), researchers evaluated the co-precipitation and precipitation equilibrium of $\mathrm{U}(\mathrm{VI})$ with $\mathrm{Fe}(\mathrm{III})$ oxides (BRUNO et al., 1995). In studies with acidic solutions of U(VI) and Fe(III) that were titrated with base, these researchers report the formation of hematite and minor goethite in suspensions that have been aged for up to three years at $25{ }^{\circ} \mathrm{C}$. Although our studies are performed under conditions that accelerated aging (aging at $60{ }^{\circ} \mathrm{C}$ ), our findings concur with the mineralogical identifications made by BRUNO et al. (1995). BRUNO et al. (1995) report sorption of U(VI) on Fe-oxide surfaces as the mechanism of uptake and they studied the kinetics of $U$ removal from solution over a range of $\mathrm{pH}$ conditions. However, these do not examine on the local structural of the incorporated $\mathrm{U}$ as in our study.

\section{CONCLUSIONS}

Collectively, the findings from our studies and those of others as mentioned indicate that the long-term association of $U$ in the contaminated environment likely results in sorption on organic (such as humic materials and living matter) and inorganic materials (minerals and soil media), precipitation of $\mathrm{U}$ as Fe-free $\mathrm{U}(\mathrm{VI})$ under oxic conditions as well as reduction under microbiallyreducing conditions as $\mathrm{U}(\mathrm{IV})$ oxide phases, and structural incorporation of $\mathrm{U}$ in other mineral host phases. These are mechanisms that can retard the transport of $U$ in aqueous systems. In nature, precipitation of pure $U$ phases will probably occur at a kinetically faster rate than that of the structural incorporation of $U$ into Fe oxides. Precipitation of $U$ as pure mineral phases such as schoepite should be favored at high dissolved U concentrations whereas sorption and coprecipitation of $U$ are most likely favored at lower dissolved $U$ concentrations. In aged, Ucontaminated Fe-rich soils, uptake of $U$ by Fe oxides may be significant since close to $1 \mathrm{~mol} \%$ $\mathrm{U}$ can be incorporated. However, few studies have focused on the incorporation of $U$ into crystalline mineral phases in natural samples so an estimate as to the importance of these mechanisms in aged, U-contaminated or U-rich materials is yet to be made.

\section{ACKNOWLEDGEMENTS}

This research was supported in part by Financial Assistance Award Number DE-FC0996SR18546 from the U.S. Department of Energy to the University of Georgia Research 
Foundation and this document was prepared with support via Contract No. DE-AC0996SR18500 with the U.S. Department of Energy. We thank P. M. Bertsch (SREL) for his support, A. J. Sowder (SREL) for assistance with the U reference materials, and B. P. Jackson (SREL) for the ICP-MS analyses. Appreciation is also given to the staff at the National Synchrotron Light Source at Brookhaven National Laboratory, T. Lanzirotti (Univ. Chicago) and B. Rao (SREL). The X26A microprobe beamline is supported in part by DOE grant DE-FG0292ER14244. Use of the X-ray beamline X23a2 and user support from J. Woicik of the National Institutes of Standards and Technology are greatly appreciated. Thanks are also given to Drs. S. Wood (WSRC) and S. D. Fink (WSRC) for support during the final stages of the preparation of this manuscript. We also thank Eichrom Industries, Inc. (Darien, IL) for supplying the Diphonix resin that we used to removed dissolved $\mathrm{U}$ as part of our waste minimization protocol. 


\section{REFERENCES}

ALLARD T., ILDEFONSE P., BEAUCAIRE C. and CALAS G. (1999) Structural chemistry of uranium associated with $\mathrm{Si}, \mathrm{Al}, \mathrm{Fe}$ gels in a granitic uranium mine. Chem. Geol. 158, 81-103.

ALLEN P. G., SHUH D. K., BUCHER J. J., EDELSTEIN N. M., PALMER P. A., SILVA R. J., NGUYEN, S. N., MARQUEZ L. N. and HUDSON E. A. (1996) Determinations of uranium structures by EXAFS: Schoepite and other U(VI) oxide precipitates. Radiochim. Acta 75, 47-3

AZENHA M. E., VAN DER VOORT D. and BLASSE G. (1992) The influence of an effective charge on the uranate luminescence in the ordered perovskite structure. J. Solid State Chem. 101, 190-194.

BARGAR J. R., REITMEYER R., LENHART J. J. and DAVIS J. A. (2000) Characterization of U(VI)-carbonato complexes on hematite: EXAFS and electrophoretic mobility measurements. Geochim. Cosmochim. Acta 64, 2737-2749.

BARGAR J. R., REITMEYER R. and DAVIS J. A. (1999) Spectroscopic confirmation of uranium(VI)-carbonato adsorption complexes on hematite. Env. Sci. Technol. 33, 2481-2484

BERTSCH P. M., HUNTER D. B., SUTTON S. R., BAJT S. and RIVERS M. L. (1994) In situ chemical speciation of uranium in soils and sediment by micro X-ray absorption spectroscopy. Env. Sci. Technol. 28, 980-984.

BATSON V. L., BERTSCH P. M. and HERBERT B. E. (1996) Transport of anthropogenic uranium from sediments to surface waters during episodic storm events. J. Environ. Qual. 25, 1129-1137.

BIWER B. M., EBERT W. L. and BATES J. K. (1990) The Raman spectra of several uranylcontaining minerals using a microprobe. J. Nucl. Mater. 175, 188-193.

BLAKE R. L., HESSEVICK R. E., ZOLTAI T. and FINGER L. W. (1966) Refinement of the hematite structure. Amer. Mineral. 51, 123-129. 
BRUNO J., De PABLO J., DURO L. and FIGUEROLA E. (1995) Experimental study and modeling of the $\mathrm{U}(\mathrm{VI})-\mathrm{Fe}(\mathrm{OH})_{3}$ surface precipitation/coprecipitation equilibria. Geochim. Cosmochim. Acta 59, 4113-4123.

BUCK E. C., BROWN N. R. and DIETZ N. L. (1996) Contaminant uranium phases and leaching at the Fernald site in Ohio. Env. Sci. Technol. 30, 81-88.

BURNS P. C. (1999) The Crystal Chemistry of Uranium. In: Uranium: Mineralogy, Geochemistry and the Environment. Reviews in Mineralogy 38, pp. 23-90, Mineral. Soc. Amer.

BURNS P. C., EWING R. C. and HAWTHORN F. C. (1997) The crystal chemistry of hexavalent uranium: Polyhedral geometries, bond-valence parameters, and polymerization of polyhedra. Can. Mineral. 35, 1551-1570.

CEJKA J. (1999) Infrared spectroscopy and thermal analyses of the uranyl minerals. In: Uranium: Mineralogy, Geochemistry and the Environment. Reviews in Mineralogy 38, pp. 521608, Mineral. Soc. Amer.

CHRIST C. L. and CLARK J. R. (1960) Crystal chemical studies of some uranyl oxide hydrates. Amer. Mineral. 45, 1026-1061.

CHISHOLM-BRAUSE C., CONRADSON S. D., BUSCHER C. T., ELLER P. G. and MORRIS D. E. (1994) Speciation of uranyl sorbed at multiple binding sites on montmorillonite. Geochim. Cosmochim. Acta 58, 3625-3631.

CHAO T. T. and L. ZHOU (1983) Extraction techniques for selective dissolution of amorphous iron oxides from soils and sediments. Soil Sci. Soc. Am. J. 47, 225-232.

CLARK S. B., JOHNSON W. H., MALEK M. A., SERKIZ S. M. and HINTON T. G. (1996) A comparison of sequential extraction techniques to estimate geochemical controls on the mobility of fission product, actinide, and heavy metal contaminants in soils. Radiochim. Acta 74, 173-179.

DENECKE M. A., REICH T., BUBNER M., POMPE S., HEISE K. H., NITSCHE H., ALLEN P. G., BUCHER J. J., EDELSTEIN N. M. and SHUH D. K. (1998) Determination of structural parameters of uranyl ions complexed with organic acids using EXAFS. J. Alloys Comp. 271-273, 123-127. 
DENT A. J., RAMSAY J. D. F. and STANTON S. W. (1992) An EXAFS study on uranyl ion in solution sorbed onto silica and montmorillonite clay colloids. J. Colloid Interface Sci. 150, 4560 .

DUFF M. C. and AMRHEIN C. (1996) Uranium(VI) adsorption on goethite and soil in carbonate solutions. Soil Sci. Soc. Amer. J. 743, 1393-1400.

DUFF M. C., AMRHEIN C., BERTSCH P. M. and HUNTER D. B. (1997) The chemistry of uranium in a San Joaquin Valley, California, USA evaporation pond sediment using X-ray fluorescence and XANES techniques. Geochim. Cosmochim. Acta 61, 73-81.

DUFF M. C., HUNTER D. B., BERTSCH P. M. and AMRHEIN C. (1999) Factors influencing uranium reduction and solubility in evaporation pond sediments. Biogeochem. 45, 95-114.

DUFF M. C., MASON C. F. V. and HUNTER D. B. (1998) Comparison of acid and base leach for the removal of uranium from contaminated soil and catch box media. Can. J. Soil Sci. 78, 675-683.

DUFF M. C., MORRIS D. E., BERTSCH P. M. and HUNTER D. B. (2000) Spectroscopic Characterization of uranium in evaporation basin sediments. Geochim. Cosmochim. Acta 64, 1535-1550.

ENG P. J., RIVERS M. L., YANG B. X. and SCHILDKAMP W. (1995) Microfocusing 4-keV to 65-keV X-rays with bent Kirkpatrick-Baez mirrors. Proc. SPIE 2516, 41-51.

ERTEN H. N., MOHAMMED A. K. and CHOPPIN G. R. (1994) Variation of stability constants of thorium and uranium oxalate complexes with ionic strength. Radiochim. Acta 66/67, 123-128.

FARGES F., PONADER C. W., CALAS G. and BROWN G. E. Jr. (1992) Structural environments of incompatible elements in silicate glass/melt systems: II. $\mathrm{U}^{\mathrm{IV}}, \mathrm{U}^{\mathrm{V}}$, and $\mathrm{U}^{\mathrm{VI}}$. Geochim. Cosmochim. Acta 56, 4205-4220.

FINCH R. J. and MURAKAMI T. (1999) Systematics and Paragenesis of Uranium Minerals. In: Uranium: Mineralogy, Geochemistry and the Environment. Reviews in Mineralogy 38, pp. 91180, Mineral. Soc. Amer. 
FINCH R. J., HAWTHORNE F. C., MILLER M. L. and EWING R. C. (1997) Distinguishing among schoepite and related minerals by X-ray diffraction. Powder Diffraction, 12, 230-238.

FORD R. G., KEMNER K. M. and BERTSCH P. M. (1999) Influence of sorbate-sorbent interactions on the crystallization kinetics of nickel- and lead- ferrihydrite co-precipitates. Geochim. Cosmochim. Acta. 63, 39-48.

FORD R. G., BERTSCH P. M. and FARLEY K. J. (1997) Changes in transition and heavy metal partitioning during hydrous iron oxide aging. Env. Sci. Technol. 31, 2028-2033.

FRANCIS A. J. (1998) Biotransformation of uranium and other actinides in radioactive wastes. J. Alloys Comp. 271-273, 78-84.

FRANCIS A. J. and DODGE C. J. (1990) Anaerobic microbial remobilization of toxic metals copreciptated with iron oxide. Env. Sci. Technol. 24, 373-378.

FREDRICKSON J. K., ZACHARA J. M., KENNEDY D. W., DUFF M. C., GORBY Y. A., LI S. W. and KRUPKA K. M. (2000) Reduction of U(VI) in goethite ( $\alpha-\mathrm{FeOOH})$ suspensions by a dissimilatory metal-reducing bacterium. Geochim. Cosmochim. Acta. 64, 3085-3098.

GERTH J. (1990) Unit-cell dimensions of pure and trace metal-associated goethites. Geochim. Cosmochim. Acta 54, 363-371.

GRENTHE I., FUGER J., KONINGS R., LEMIRE R. J., MULLER A. B., NGUYEN-TRUNG C. and WANNER J. (1992). The chemical thermodynamics of uranium. Elsevier Sci. Publ., New York.

GRIFFITHS T. R. and VOLKOVICH V. A. (1999). A review of the high termperature oxidation of uranium oxides in molten salts and in the solid state to form alkali metal uranates, and their composition and properties. J. Nucl. Materials, 274, 229-251.

HANCHAR J. M. (1999). Spectroscopic techniques applied to uranium in minerals. Reviews in Mineralogy, 38, 499-519.

HO C. H. and MILLER N. H. (1986) Adsorption of uranyl from bicarbonate solution onto hematite particles. J. Coll. Interface Sci. 110, 165-171. 
HOBBS D. T. and KARRAKER D. G. (1996) Recent results on the solubility of uranium and plutonium in Savannah River Site waste supernate. Nucl. Technol. 114, 318-324.

HSI C-K. D. and LANGMUIR D. (1985). Adsorption of uranyl onto ferric oxyhydroxides: Applications of the surface complexation site-binding model. Geochim. Cosmochim. Acta 49, 1931-1941.

HUDSON E. A., REHR J. J. and BUCHER J. J. (1995) Multiple-scattering calculations of the uranium $\mathrm{L}_{\mathrm{III}}$-edge X-ray-absorption near-edge structure. Phys. Rev. B.-Condens. Matt, 52, 13815-13826.

HUNTER D. B. (2001) Rotate_Atoms. Westinghouse Savannah River Company. Aiken, SC, 29808.

HUNTER D. B. and BERTSCH P. M. (1998) In situ examination of uranium contaminated soil particles by micro-X-ray absorption and microfluorescence spectroscopies. J. Radioanaly. Nucl. Chem. 234, 237-242.

JENNE E. A. (1977) Trace element sorption by sediments and soils - Sites and processes. IN: Molybdenum in the Environment. CHAPPEL W. and PETERSON K., Eds. Marcel Dekker: New York, p. 425-553.

KHILLA M. A., EL-FEKEY S. A. and ROFAIL N. H. (1986) Infrared absorption study of uranium trioxide phases. Radiochim. Acta 40, 185-190.

KOCHAN I. G. and SHUKTOMOVA L. I. (1990) Reduction of the influence of luminescence quenchers in the determination of U(VI) in soils. J. Analyt. Chem. USSR 45, 1337-1339.

LERCEL M. J., CRAIGHEAD H. G., PARIKH A. N., SESHAD R. I. and ALLARA D. L. (1996) Sub-10 nm lithography with self-assembled monolayers. Appl. Phys. Lett. 68, 1504-1506.

LOVLEY D. R., PHILLIPS E. J. P., GORBY Y. A. and LANDA E. R. (1991) Microbial uranium reduction. Nature 350, 413-416. 
MACASKIE L. E., EMPERSON R. M., CHEETHAM A. K., GREY C. P. and SKARNULIS A. J. (1992) Uranium bioaccumulation by a Citrobacter sp. as a result of enzymatically mediated growth of polycrystalline $\mathrm{HUO}_{2} \mathrm{PO}_{4}$. Science 257, 782-784.

MARTINEZ C. E. and MCBRIDE M. B. (1998) Co-precipitates of $\mathrm{Cd}, \mathrm{Cu}, \mathrm{Pb}$, and $\mathrm{Zn}$ in iron oxides: Solid phase transformations and metal solubility after aging and thermal treatment. Clays Clay Min. 46, 537-545.

MASON C. F. V., DUFF, M. C., MUSGRAVE J. A. and RUNDE W. (1996) Interim report on remedial actions for Yuma catch-boxes. Los Alamos National Laboratory, Los Alamos, NM. LA-UR-96-3485.

MILLER W. P., MARTINS D. C. and ZELAZNY L. W. (1986) Effect of sequence in extraction of trace metals from soils. Soil Sci. Soc. Am. J. 50, 598-601.

MORRIS D. E., ALLEN P. G., BERG J. M., CHISHOLM-BRAUSE C. J., CONRADSON S. D., DONOHOE R. J., HESS N. J., MUSGRAVE J. A. and TAIT C. D. (1996) Speciation of uranium in Fernald soils by molecular spectroscopic methods: Characterization of untreated soils. Env. Sci. Technol. 30, 2322-2331.

MOYES L. N., PARKMAN R. H., CHARNOCK D. J., LIVENS F. T., HUGHES C. R. and BRAITHWAITE A. (2000) Uranium uptake from aqueous solution by interaction with goethite, lepidocrocite, muscovite and mackinawite: An X-ray absorption spectroscopy study. Env. Sci. Technol. 34, 1062-1068.

NANGANO T., MITAMURA H., NAKAYAMA S. and NAKASHIMA S. (1999) Formation of goethite and hematite from neodymium-containing ferrihydrite suspensions. Clays Clay Min. 47, 748-754.

NEWVILLE M., LIVINS P., YACOBY Y., REHR J. J. and STERN E. A. (1993) Near-edge Xray-absorption fine-structure of $\mathrm{Pb}-\mathrm{A}$ comparison of theory and experiment. Phys. Rev. BCond. Matter 47, 14126-14131.

NYQUIST R. A. and KAGEL R. O. (1997) Infrared spectra of inorganic componds. Volume 4. Academic Press, INC. San Diego, CA. 
OHNUKI T., ISOBE I., YANASE N., NAGANO T., SAKAMOTO T. and SEKINE K. (1997) Change in sorption characteristics of uranium during crystallization of amorphous iron minerals. J. Nucl. Sci. Technol. 34, 1153-1158.

PEARCY E. C., PRIKYL J. D. and LESLIE B. W. (1994) Alteration of uraninite from the Nopal I deposit, Peña Blanca District, Chihuahua, Mexico, compared to degradation of spent fuel in the proposed U.S. high-level nuclear waste repository at Yucca Mountain, Nevada. Appl. Geochem. 9, 713-732.

PLOTNIKOV V. I. and BANNYKH V. I. (1997) Sorption of uranium(VI) by metal hydroxides. II. Sorption of uranium(VI) by trivalent metal hydroxides. Radiochem. 39, 162-164.

RAZIK A. A., ALI F. A. and ATTIA F. A. (1989) Evaluation of the stability constants of uranyl association complexes with phosphate, oxalate, tartrate, and citrate anions in solutions of constant ionic strength. Microchem. J. 39, 265-269.

READ D., BENNETT D. G., HOOKER P. J., IVANOVICH M., LONGWORTH G., MILODOWSKI A. E. and NOY D. J. (1993) The migration of uranium into peat-rich soils at Broubster, Caithness, Scotland, U.K. J. Contam. Hydrol. 13, 291-308.

REEDER R. J., NUGENT M., LAMBLE G. M., TAIT C. D. and MORRIS D. E. (2000) Uranyl incorporation into calcite and aragonite: XAFS and luminescence studies. Env. Sci. Technol. 34, 638-644.

REHR J. J. and ALBERS R. C. (1990) Scattering-matrix formulation of curved-wave multiplescattering theory: Application to x-ray-absorption fine structure. Phys. Rev. B41, 8139.

REHR J. J., MUSTRE de LEON J., ZABINSKY S. I. and ALBERS R. C. (1991) Theoretical Xray absorption fine structure standards. J. Am. Chem. Soc. 113, 5135.

REHR J. J., ZABINSKY S. I. and ALBERS R. C. (1992) High-order multiple scattering calculations of x-ray-absorption fine structure. Phys. Rev. Lett. 69, 3397.

RESSLER T. (1998) WinXAS. A program for x-ray absorption spectroscopy data analysis under ms windows. J. Synchr. Rad. 5, 118-122. 
SATO T., MURAKAMI T., YANASE N., ISOBE H., PAYNE T. E. and AIREY P. L. (1997) Iron nodules scavenging uranium from groundwater. Env. Sci. Technol. 31, 2854-2858.

SCHWERTMANN U. and CORNELL R. M. (1991) In Iron Oxides in the Laboratory: Preparation and characterization. VCH Publishers, NY.

SHANNON R. D. (1976) Revised effective ionic radii and systemic studies of interatomic distances in halides and chalcogenides. Acta Cryst. A32, 751-767.

SMITH J. V. and RIVERS M. L. (1995) In Synchrotron X-ray microanalysis in microprobe techniques in the earth sciences, POTTS P. J. et al., Eds. 163-233, Chapman and Hall, London.

SOBRY R. (1973) Etude des "uranates" hydrates- II: Examen des proprietes vibrationnelles des uranates hydrates de cations bivalents J. Inorg. Nucl. Chem. 35, 2753-2768.

SWARZENKSKI P.W., MCKEE B. A., SKEI J. M. and TODD, J. F. (1999) Uranium biogeochemistry across the redox transition zone of a permanently stratified fjord: Framvaren, Norway. Mar. Chem. 67, 181-198.

TANNER P. A., ZHI-WU P., JUN L., YULONG L. and QIANG S. (1997) Luminescence of uranium-doped strontium tetraborate. J. Phys. Chem. Solids 58, 1143-1146.

TEMPLETON D. H. and TEMPLETON L. K. (1982) X-ray dichroism and polarized anomalous scattering of the uranyl ion. Acta Cryst. A38, 62-67.

THOMPSON H. A., BROWN G. E. and PARKS G. A. (1997) XAFS spectroscopic study of uranyl coordination in solids and aqueous solution. Amer. Mineral. 82, 483-496.

U.S. D.O.E. (1999) From Cleanup to Stewardship. U.S. D.O.E. Office Environ. Management, Oct.

WAITE T. D., DAVIS J. A., PAYNE T. E., WAYCHUNAS G. A. and XU N. (1994) Uranium adsorption to ferrihydrite: Application of a surface complexation model. Geochim. Cosmochim. Acta. 58, 5465-5478. 
WEIGEL F. (1986) Uranium. In The Chemistry of the Actinide Elements, $2^{\text {nd }}$ Edition (eds. J.J. Katz et al.,), Vol. 1, Chap. 5, pp. 169-442. Chapman and Hall.

WERSIN P., HOCHELLA M. F. JR., PERSSON P., REDDEN G., LECKIE J. O. and HARRIS D. W. (1994) Interaction between aqueous uranium(VI) and sulfide minerals: Spectroscopic evidence for sorption and reduction. Geochim. Cosmochim. Acta 58, 2829-2843.

YANG B. X., RIVERS M. L., SCHILDKAMP W. and ENG P. (1995) GEOCARS microfocusing Kirkpatrick-Baez mirror bender development. Rev. Sci. Instrum. 66, 2278. 
Table 1. Uranium mole fraction and IR peak assignments for $\mathrm{CO}_{3}$-free synthetic solids, before and after carbonate and oxalate extraction. Schoepite (this study) and high $\mathrm{pH}$ (altered) schoepite reference spectra (ALLEN et al. 1996) also shown.

\begin{tabular}{|c|c|c|c|c|c|c|c|c|}
\hline \multirow{3}{*}{ Sample } & \multirow{6}{*}{$\begin{array}{l}\text { Solid Phase } \\
\text { U mol\% }\end{array}$} & \multirow{6}{*}{400} & \multicolumn{6}{|c|}{ IR Peak Position and Assignments $\left(\mathrm{cm}^{-1}\right)^{\mathrm{a}}$} \\
\hline & & & 500 & \multirow{2}{*}{\multicolumn{2}{|c|}{$\begin{array}{l}\text { IR Peak Position } \\
600 \\
560\end{array}$}} & \multirow{2}{*}{$\begin{array}{l}800 \\
796\end{array}$} & \multicolumn{2}{|c|}{900} \\
\hline & & & 470 & & & & 893 & \multirow{4}{*}{$\begin{array}{l}930 \\
\text { Uranyl ion } \\
\text { asymmetric } \\
\text { stetch, } v_{3}\end{array}$} \\
\hline & & & \multirow{2}{*}{\multicolumn{2}{|c|}{$\begin{array}{c}\text { Hematite } \\
\text { Fe-O }\end{array}$}} & & \multirow{2}{*}{\multicolumn{2}{|c|}{$\begin{array}{l}\text { Goethite } \\
\text { Fe-O-H }\end{array}$}} & \\
\hline & & & & & & & & \\
\hline & & & \multicolumn{2}{|c|}{\begin{tabular}{c}
\multicolumn{2}{|}{$\mathbf{F e}-\mathbf{O}$} \\
Bend
\end{tabular}} & & \multicolumn{2}{|c|}{ Bend Bend } & \\
\hline \multicolumn{9}{|c|}{ Unleached Solids } \\
\hline FeU21 & 5.4 & & $472 \mathrm{~ms}$ & $560 \mathrm{~s}$ & $699 \mathrm{sh}$ & & & $936 \mathrm{~m}$ \\
\hline FeU $1^{\mathrm{d}}$ & 3.5 & & $473 \mathrm{~s}$ & $556 \mathrm{~s}$ & & $797 \mathrm{w}$ & & $928 \mathrm{~s}$ \\
\hline FeU23a & 3.5 & & $472 \mathrm{~ms}$ & $557 \mathrm{~s}$ & $697 \mathrm{sh}$ & & & $929 \mathrm{~m}$ \\
\hline FeU23b & 2.4 & $403 \mathrm{w}$ & $468 \mathrm{~ms}$ & $551 \mathrm{~s}$ & & $796 \mathrm{~m}$ & $893 \mathrm{~m}$ & $931 \mathrm{sh}$ \\
\hline FeU24b & 1.2 & & $469 \mathrm{~ms}$ & $552 \mathrm{~s}$ & $699 \mathrm{sh}$ & $794 \mathrm{~m}$ & $894 \mathrm{~m}$ & \\
\hline FeU24a & 0.55 & $404 \mathrm{w}$ & $473 \mathrm{~m}$ & $560 \mathrm{~s}$ & & $796 \mathrm{~m}$ & $893 \mathrm{~m}$ & \\
\hline FeU22 & 0.68 & $397 \mathrm{~m}$ & $472 \mathrm{~ms}$ & $560 \mathrm{~s}$ & $699 \mathrm{sh}$ & $793 \mathrm{~m}$ & $892 \mathrm{~m}$ & \\
\hline $\mathrm{FeU}^{\mathrm{d}}$ & 0.54 & $404 \mathrm{w}$ & $472 \mathrm{~ms}$ & $561 \mathrm{~s}$ & & $794 \mathrm{~m}$ & $892 \mathrm{~m}$ & \\
\hline FeU42a & 1.1 & & $471 \mathrm{~ms}$ & $559 \mathrm{~s}$ & $695 \mathrm{sh}$ & $782 \mathrm{w}$ & $881 \mathrm{w}$ & $907 \mathrm{n}$ \\
\hline $\mathrm{FeU} 42 \mathrm{~b}$ & 1.0 & & $473 \mathrm{~ms}$ & $555 \mathrm{~s}$ & $695 \mathrm{sh}$ & $779 w$ & & $905-896 \mathrm{vbr}$ \\
\hline \multicolumn{9}{|c|}{ After Carbonate Leaching } \\
\hline FeU21 & 0.78 & & $471 \mathrm{~m}$ & $556 \mathrm{~s}$ & $697 \mathrm{vw}$ sh & & & 907 vw br \\
\hline FeU1 & 0.91 & & $475 \mathrm{~m}$ & $572 \mathrm{~s}$ & $696 \mathrm{vw} \mathrm{sh}$ & & & $906 \mathrm{vw}$ br \\
\hline FeU23a & 0.61 & & $472 \mathrm{~m}$ & $558 \mathrm{~s}$ & $700 \mathrm{vw} \mathrm{sh}$ & & & 924 vw br \\
\hline FeU23b & 0.65 & & $467 \mathrm{~s} \mathrm{n}$ & $554 \mathrm{sn}$ & $698 \mathrm{vw} \mathrm{sh}$ & $795 \mathrm{~m}$ & $893 \mathrm{~m}$ & \\
\hline FeU24a & 0.35 & $404 \mathrm{w} \mathrm{n}$ & $471 \mathrm{~s}$ & $561 \mathrm{~s}$ & $695 \mathrm{vw} \mathrm{sh}$ & $796 \mathrm{~m}$ & $893 \mathrm{~m}$ & \\
\hline FeU24b & 0.48 & & $475 \mathrm{~m}$ & $563 \mathrm{~s}$ & $698 \mathrm{vw} \mathrm{sh}$ & $795 \mathrm{~m}$ & $896 \mathrm{~m}$ & \\
\hline FeU22 & 0.69 & $402 \mathrm{w}$ & $461 \mathrm{~s}$ & $548 \mathrm{~s}$ & $694 \mathrm{vw} \mathrm{sh}$ & $793 \mathrm{~m}$ & $892 \mathrm{~m}$ & \\
\hline FeU2 & $\mathrm{nd}^{\mathrm{e}}$ & nd & & & & & & \\
\hline \multicolumn{9}{|c|}{ After Oxalate Leaching } \\
\hline FeU42a & 0.78 & & $471 \mathrm{~ms}$ & $559 \mathrm{~s}$ & & & $881 \mathrm{~W}$ & 909 \\
\hline FeU42b & 0.83 & & $473 \mathrm{~ms}$ & $555 \mathrm{~s}$ & & & & 908 \\
\hline \multicolumn{9}{|c|}{ Standards } \\
\hline \multicolumn{3}{|c|}{ Synth.Schoepite ${ }^{i}$} & \multicolumn{3}{|c|}{$455-554 \mathrm{w}$} & & 854,841 & $933 \mathrm{w}$ \\
\hline \multicolumn{3}{|c|}{$\begin{array}{l}\text { Synthetic Schoepite } \\
\text { in } \mathrm{pH} 11 \text { Solution }\end{array}$} & \multicolumn{3}{|c|}{$400-550 \mathrm{vbr}$} & & & 865 \\
\hline
\end{tabular}

\footnotetext{
(a) $\mathrm{s}=$ strong, $\mathrm{m}=$ medium, $\mathrm{w}=$ weak, $\mathrm{sh}=$ shoulder, br=broad, $\mathrm{n}=$ noisy, $\mathrm{v}=$ very.

(b) Mole fraction $=\mathrm{U} /(\mathrm{U}+\mathrm{Fe})$. The wt. \% $\mathrm{U}$ of samples range between 1-12\%.

(c) All solids aged 4 weeks, dialyzed and dried unless noted.

(d) Aged 24hours.

(e) No data.

(f) $95 \%$ confidence interval.

(g) Average U mol. fraction post carbonate leach: $0.59 \pm 0.2$.

(h) From Allen et al. (1996).

(i) Spectra for synthetic schoepite (this study) between 600 and $390 \mathrm{~cm}^{-1}$ resemble that of schoepite (pH 7) as shown in Figure 4 in Allen et al. (1996).
} 


\section{LIST OF FIGURES}

FIG. 1. Mechanisms by which U mobility can be retarded in the surface and subsurface geologic environment. a) Precipitation of U(VI) and U(IV) phases can limit U transport. b) Microbial uptake (internal or external) of $U$ can limit $U$ mobility in the environment. c) Sorption of $U$ by organic or inorganic matter such as humic acids and Fe oxides (respectively). d) occlusion of $U$ by clay and metal oxide coatings. e) Under reducing conditions, the formation of surface rinds of U(IV) on U(VI) minerals can also limit U mobility because U(IV) solids are less soluble. f) Co-precipitation of $\mathrm{U}$ with amorphous and crystalline minerals is another mechanism.

FIG. 2. Powder X-ray diffraction spectra for hematite, the synthetic U-Fe oxide co-precipitates and the synthetic mineral meta-schoepite.

FIG. 3. FT-IR spectra for hematite, the synthetic U-Fe oxide co-precipitates (FeU21 and FeU22) and the synthetic mineral meta-schoepite. Three of the spectra for the samples are adjusted linearly so that their absorbance peaks are proportional to that of meta-schoepite.

FIG. 4. Luminescence images of a) FeU21 and b) FeU22 and c) luminescence spectra for FeU21, FeU22 and meta-schoepite.

FIG. 5. Scanning electron microscopic images of a) hematite (SE), b) hematite (BSE), c) FeU21 (SE), d) FeU21 (BSE), e) FeU22 (SE) and f) FeU22 (BSE).

FIG. 6. The U XANES spectra ( $\mathrm{L}_{3}$ edge) for $\mathrm{U}(\mathrm{IV}) \mathrm{O}_{2}$, the $\mathrm{U}(\mathrm{VI})$ mineral meta-schoepite, the FeU2 and FeU22 U-Fe oxide co-precipitate samples. XANES spectra for uranyl nitrate contained post edge MSR features typically observed for uranyl-containing solids (data not shown).

FIG. 7. Uranium EXAFS spectra ( $\mathrm{L}_{3}$ edge) a) chi and b) Fourier transform and model fit data for the U-Fe oxide co-precipitate sample, FeU22. The Fourier transform data are uncorrected for phase shift.

FIG. 8. Molecular models of the association of $\mathrm{U}^{6+}$ with distorted Fe octahedra from the hematite structure. a) Uranium bound via the unshared faces of distorted hematite Fe octahedra at a radial U-Fe distance as short as $3.0 \AA$ and $\mathbf{b}$ ) sorbed $U$ on edges of Fe octahedra typically resides at radial U-Fe distance ranging from 3.4 to $\sim 3.5 \AA$ (BARGAR et al., 2000 and others). The hematite $\mathrm{Fe}$ octahedra exhibit face- and edge-sharing, which results in substantial structural 


\section{WSRC-MS-2002-00322}

distortion and straining. Unshared faces have the Fe-O bond lengths of $1.945 \AA$ and shared faces have Fe-O bond distances of $2.116 \AA$ (BLAKE et al., 1960). 
A) Precipitation of U(VI) and U(VI)

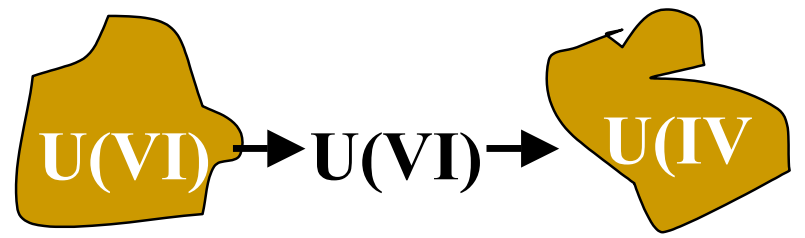

solid dissolved solid
D) Occlusion by clay and oxide coatings

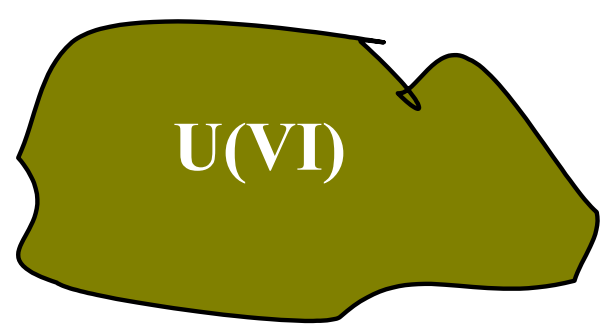

E) Formation of U(IV) oxide surface coatings on U(VI) solids

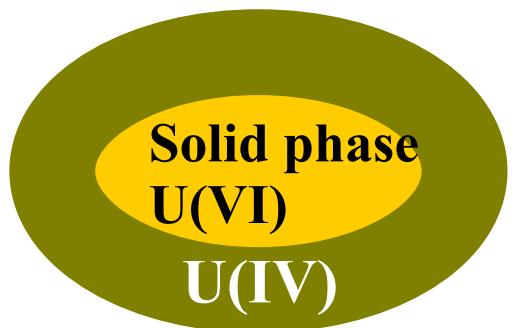

F) Co-precipitation of $\mathrm{U}$ with $\mathrm{Fe}$ and $\mathrm{Mn}$ oxides and substitution in silicate clays and carbonates

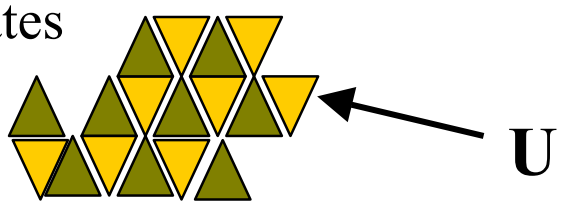

FIG.1 


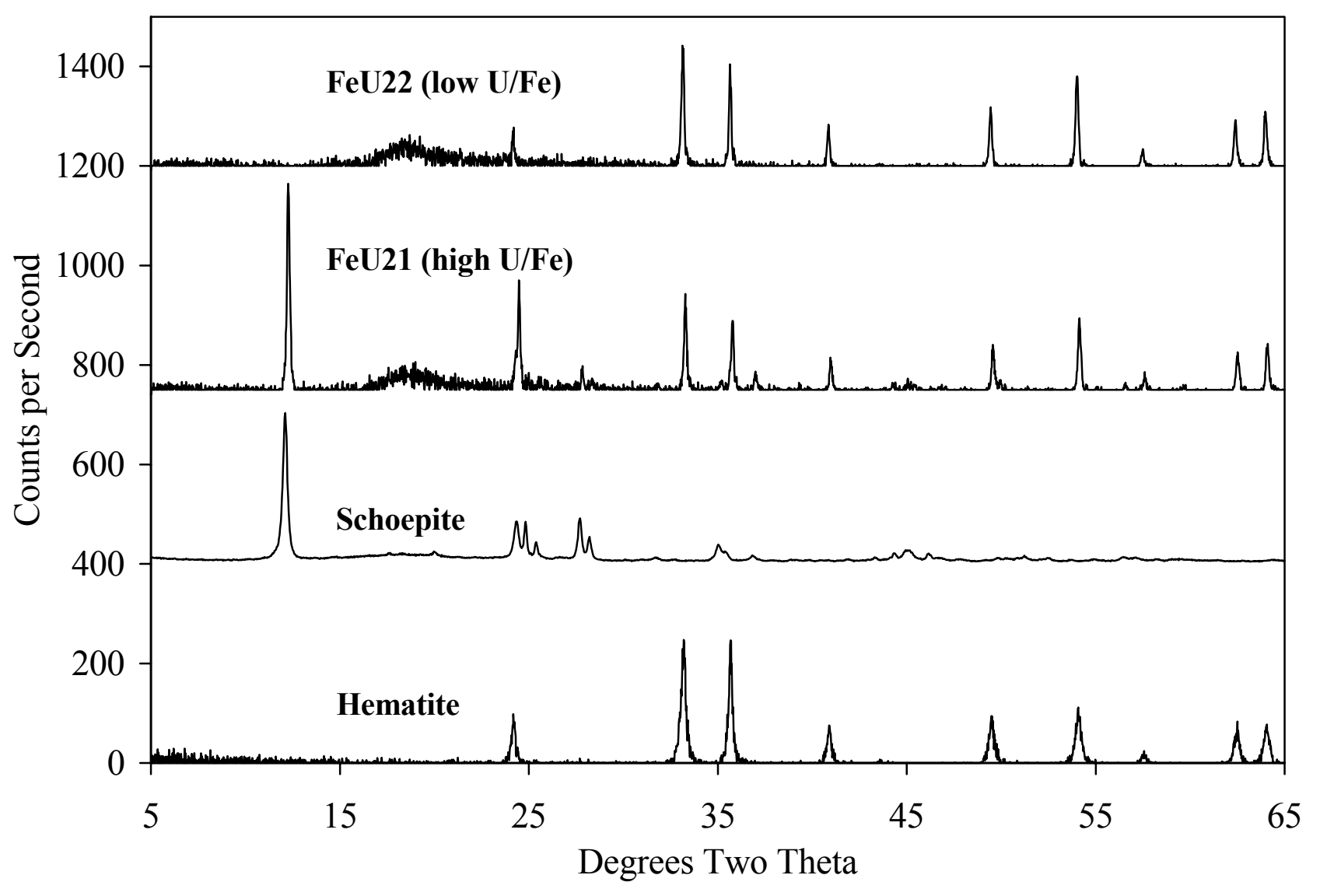

FIG. 2. 


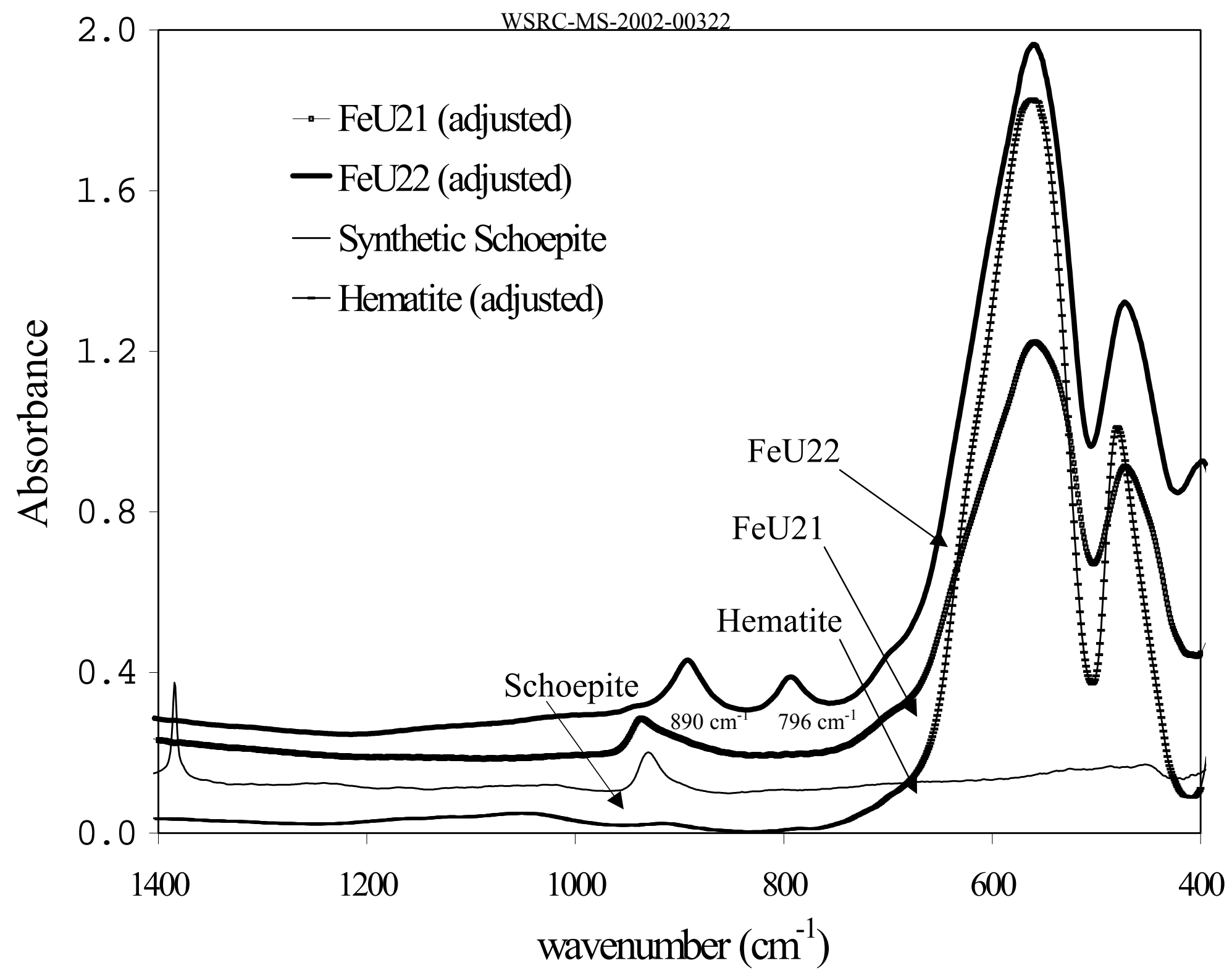

FIG. 3. 

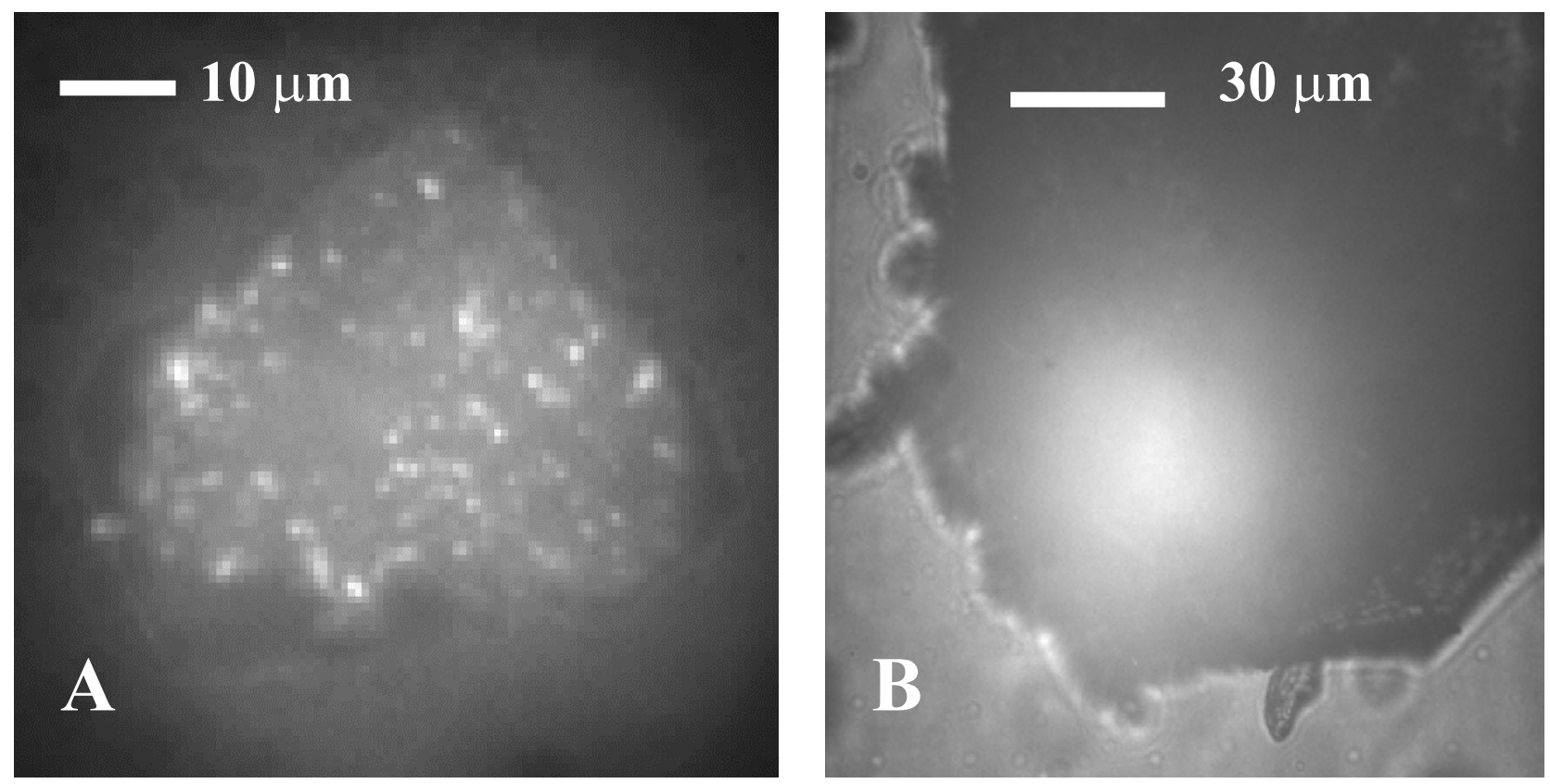

C

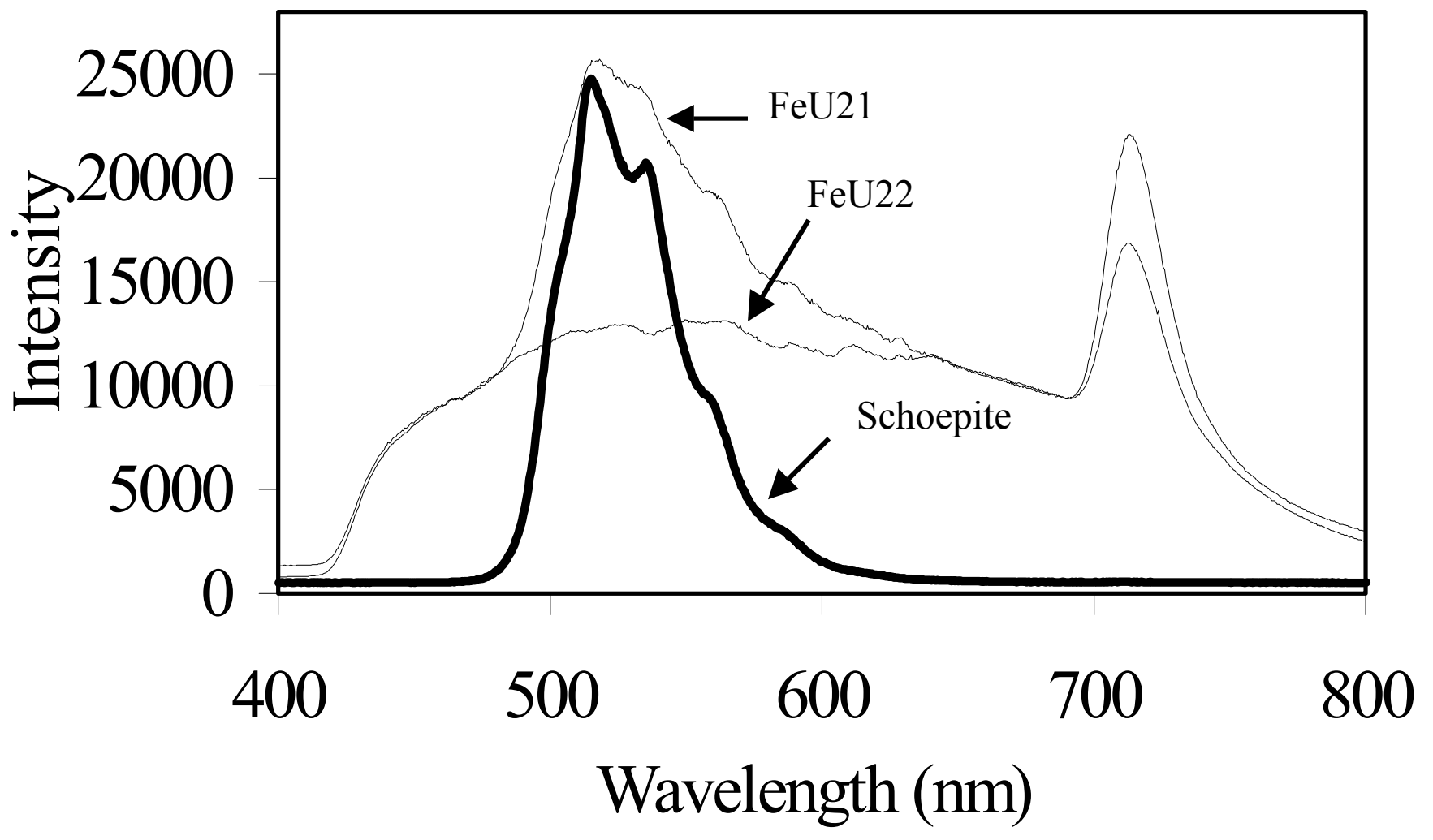

FIG. 4. 
WSRC-MS-2002-00322
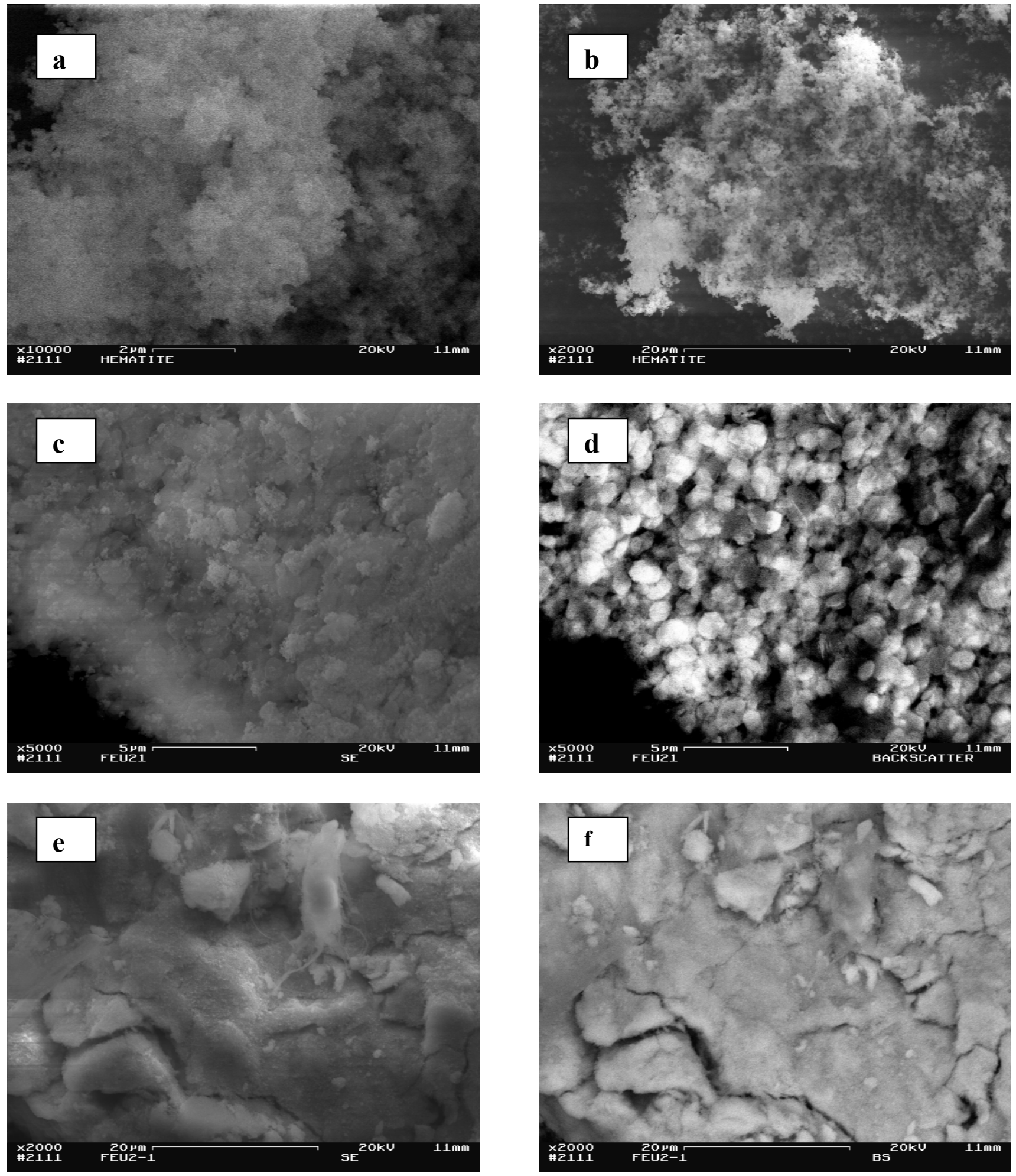

FIG. 5 


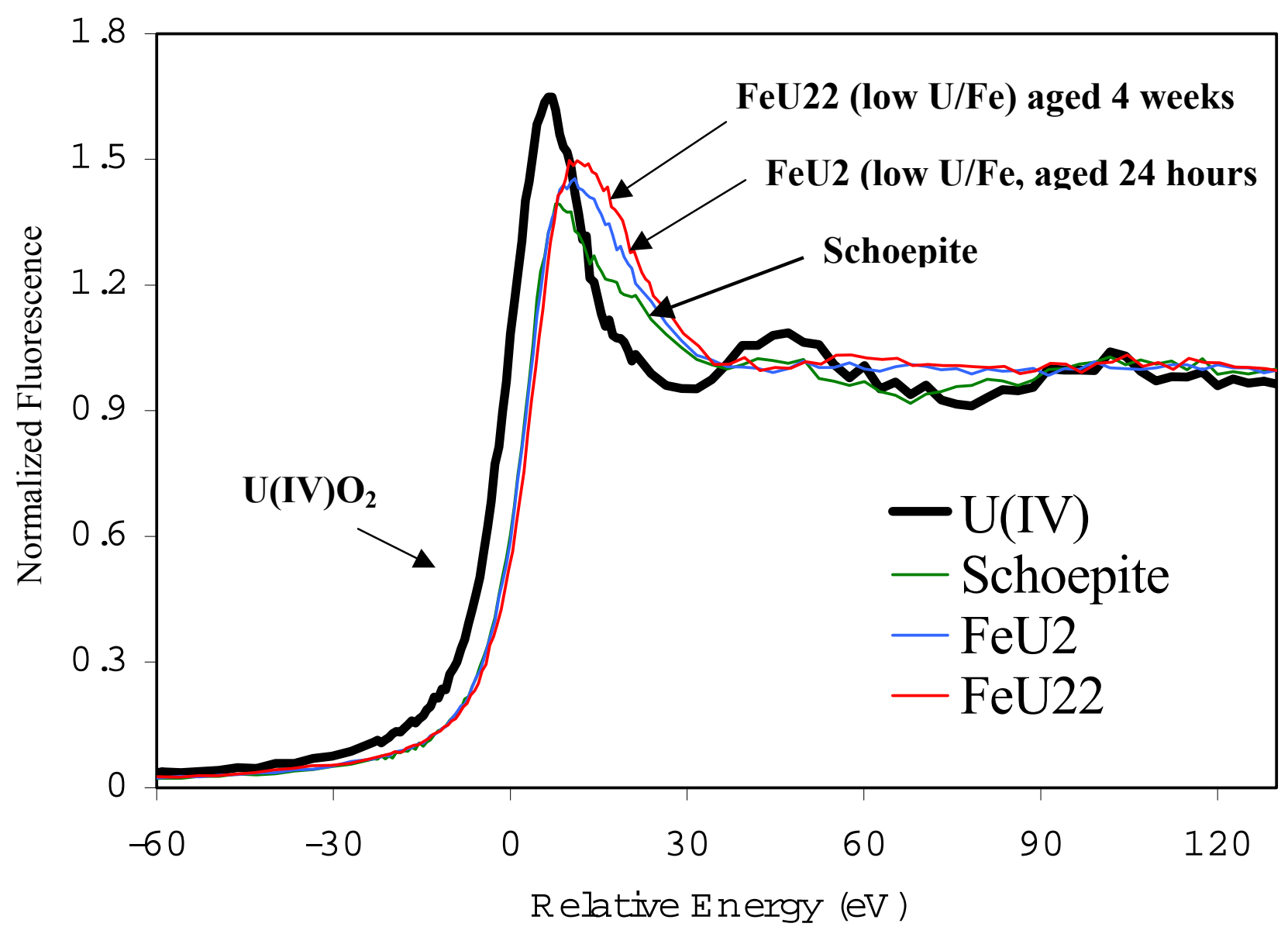

FIG. 6 
$\mathbf{a}$

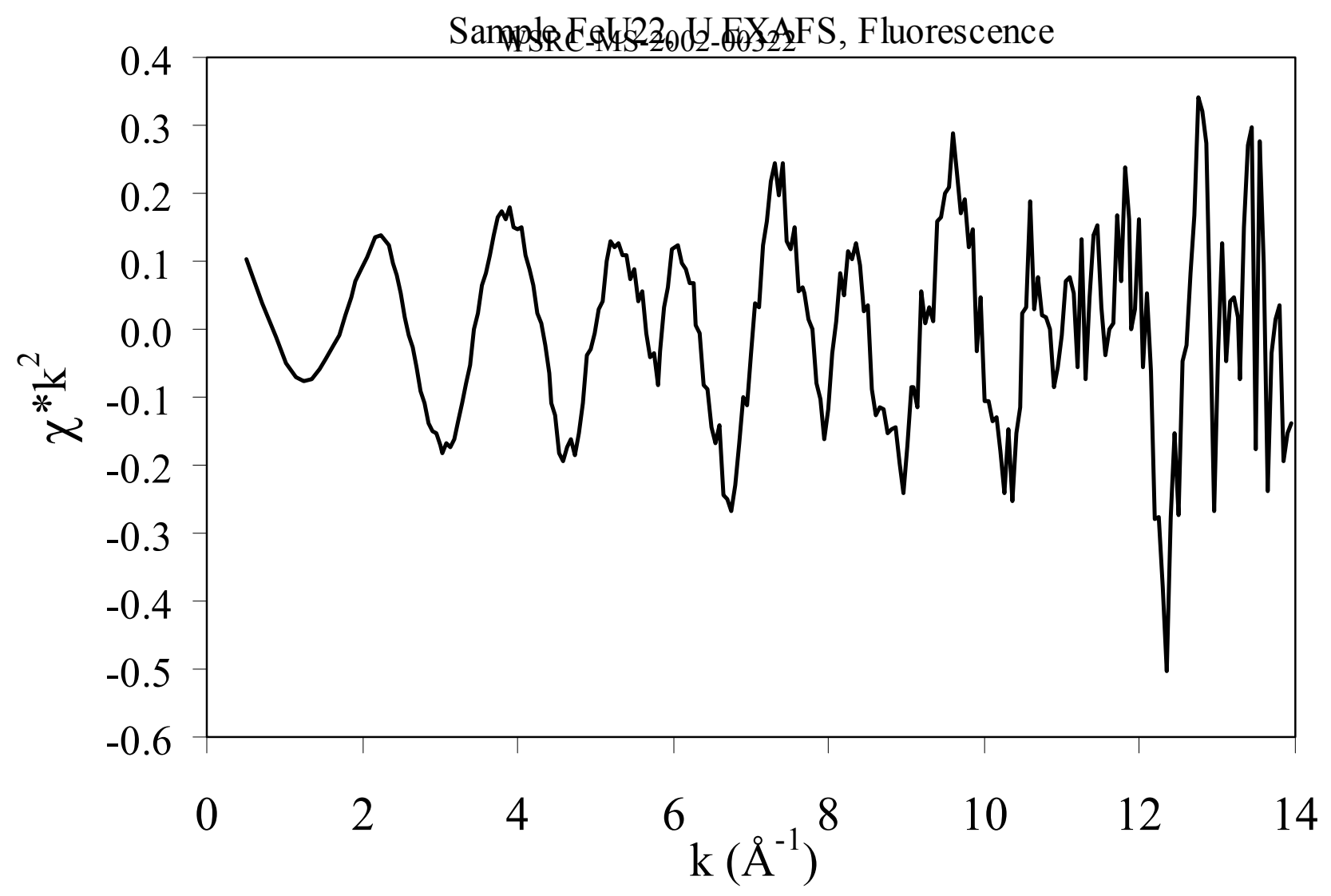

Sample FeU22, aged 4 weeks, U EXAFS, Fluorescence

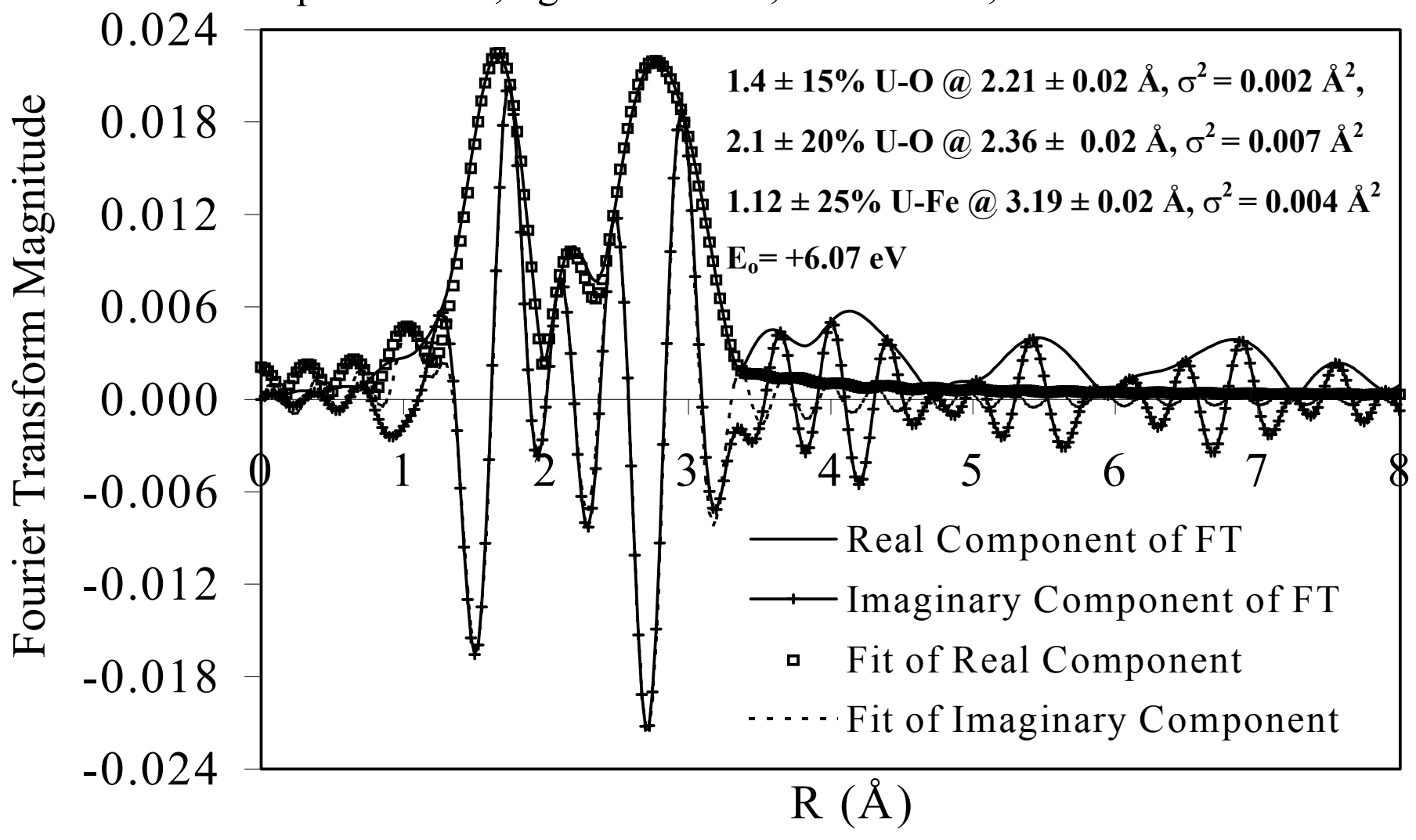

FIG. 7 
WSRC-MS-2002-00322

a

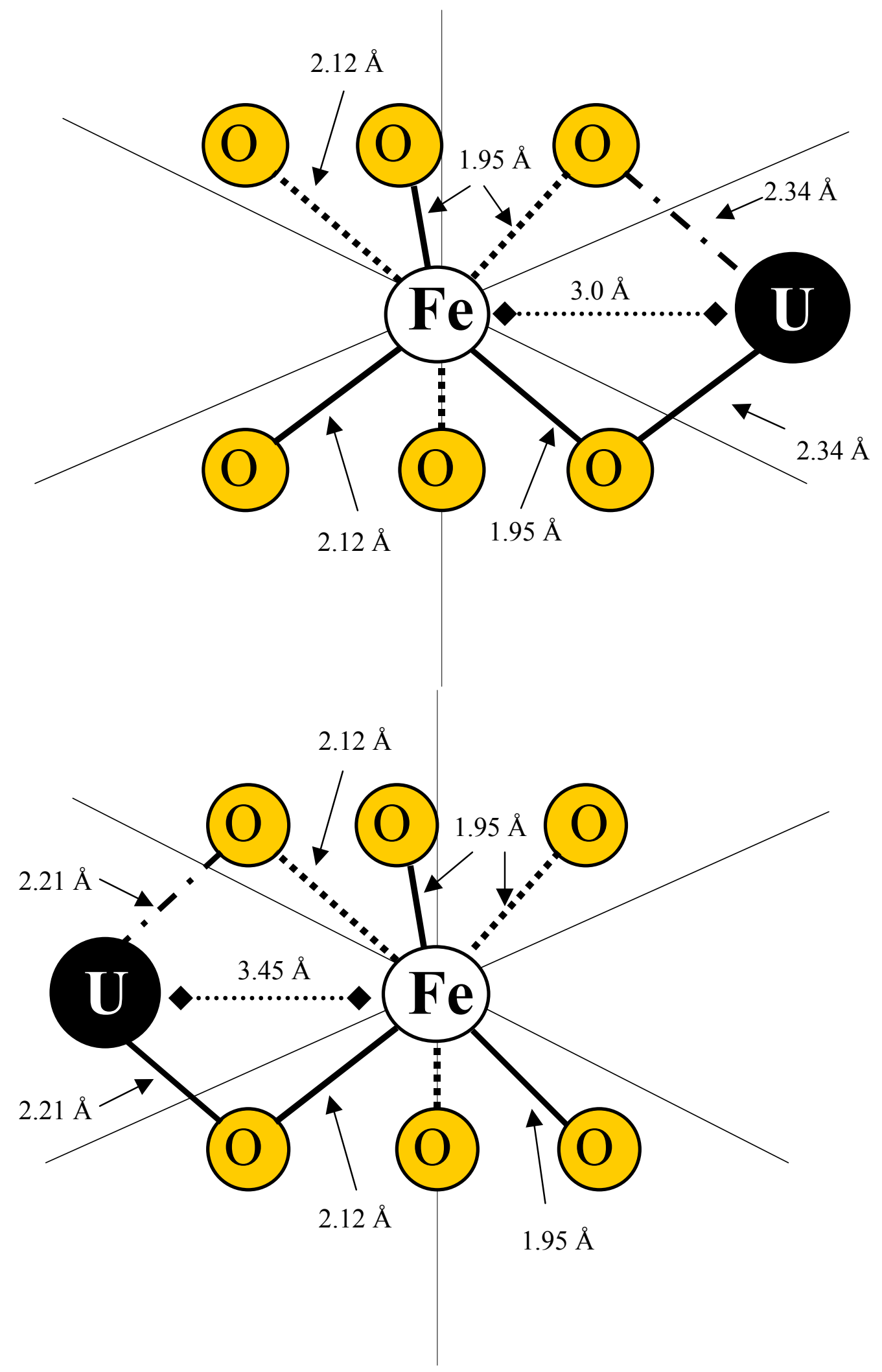

FIG. 8 